\title{
Meta-analysis of the effects of prepartum dietary protein on performance of dairy cows
}

\author{
A. Husnain and J. E. P. Santos* \\ Department of Animal Sciences, DH Barron Reproductive and Perinatal Biology Research Program, University of Florida, Gainesville 32611
}

\section{ABSTRACT}

The objectives were to review the published literature and use meta-analytic methods to determine the effects of dietary protein fed prepartum on productive performance of dairy cows. The hypothesis was that responses to dietary protein prepartum would differ between nulliparous and parous cows, and performance would be maximized at a greater protein supply in nulliparous than in parous cows. The literature was systematically reviewed, searching randomized experiments in which the prepartum dietary content or degradability of protein was manipulated. Twenty-seven experiments including 125 treatment means and 1,801 cows were included in the meta-analysis. Of those, 8 experiments with 27 treatment means reported responses for 510 nulliparous cows. Data collected included the ingredient composition and chemical analyses of prepartum diets, parity group, and means and respective measures of variance for productive responses. Mixed model meta-analysis was conducted and statistical models investigated the effects of dietary crude protein (CP) or supply of metabolizable protein (MP) prepartum on performance. Supply of MP was predicted using the National Research Council Nutrient Requirements of Dairy Cattle (2001) model. The mean \pm standard deviation and median (range) concentrations of dietary $\mathrm{CP}$ fed to cows prepartum were $14.4 \pm 2.2$ and $14.4 \%$ (8.9 to $20.9 \%$ ), resulting in mean and median (range) intakes of $\mathrm{CP}$ prepartum of $1,720 \pm 432$ and $1,734 \mathrm{~g} / \mathrm{d}$ (745 to $2,482 \mathrm{~g} / \mathrm{d}$ ). Predicted prepartum supply of MP averaged $822 \pm 157$ in nulliparous cows, ranging from 517 to $1,094 \mathrm{~g} / \mathrm{d}$, and $1,146 \pm 316$ in parous cows, ranging from 463 to $1,733 \mathrm{~g} / \mathrm{d}$. Increasing prepartum $\mathrm{CP}$ content or predicted supply of MP improved postpartum dry matter intake in nulliparous cows, but increasing prepartum $\mathrm{CP}$ content reduced prepartum dry matter intake in parous cows. Yields of milk and fat-corrected milk increased with increasing prepartum supply of MP

Received November 25, 2018.

Accepted July 9, 2019.

*Corresponding author: jepsantos@ufl.edu in nulliparous but not in parous cows. Yields of fat and protein increased in nulliparous cows with increased $\mathrm{CP}$ content or supply of MP. Alternatively, in parous cows, yield of milk fat was not influenced by supply of MP but responded quadratically to dietary $\mathrm{CP}$ content and was maximized at approximately $14 \%$ CP. Dietary $\mathrm{CP}$ had no effect on protein yield in parous cows, but increasing the supply of MP improved protein yield only in cows from experiments with $>36 \mathrm{~kg} / \mathrm{d}$ of milk production, whereas MP supply had no effect on protein yield of parous cows from experiments with $<28$ $\mathrm{kg} / \mathrm{d}$ of milk production. Performance of dairy cows was responsive to prepartum supply of MP and nulliparous benefited from diets with increased MP intake. Based on current results, production responses for nulliparous cows increased linearly up to the maximum MP intake of $1,100 \mathrm{~g} / \mathrm{d}$ observed in the study, whereas for parous cows, only yield of milk protein in cows producing more than $36 \mathrm{~kg}$ of milk/d was influenced by supplying more than $800 \mathrm{~g} / \mathrm{d}$ of MP.

Key words: meta-analysis, prepartum, protein, transition cow

\section{INTRODUCTION}

Manipulation of diet composition prepartum can have long-lasting effects on the subsequent lactation. In general, dry cows are fed diets to meet the nutrient needs of the dam and offspring while avoiding excessive nutrient intake to minimize body fat gain (Drackley, 1999). Cows in the last 3 wk of gestation are fed diets to meet their nutrient needs but these same diets are formulated with the aim of minimizing the risk of peripartum metabolic disorders (Drackley, 1999; Drackley and Cardoso, 2014; Lean et al., 2014).

Manipulating the concentration of dietary protein or the degradability of the protein source might influence intake of CP or supply of MP. Numerous experiments have been conducted to evaluate the effect of level of dietary protein, type of protein supplement with distinct ruminal degradability or supply of rumen-protected AA fed prepartum on postpartum production performance of dairy cows. Although cows require amounts of spe- 
cific AA, experiments are conducted without knowing the exact AA supply because the duodenal flow of AA is often not measured and varies with the software model used for estimation.

The NRC (2001) estimated that the daily MP requirement for a Holstein cow approaching calving is approximately $480 \mathrm{~g}$ for maintenance and $340 \mathrm{~g}$ for gravid uterus accretion when the calf is born with 42 $\mathrm{kg}$ of BW, with values based on the work by Bell et al. (1995). Such amounts of MP are easily achieved with diets containing 11 to $13 \% \mathrm{CP}$ if intakes of $\mathrm{DM}$ and energy are not limited. Accretion of mammary tissue occurs prepartum (Capuco et al., 1997; McNeill et al., 1997), and an additional $120 \mathrm{~g} / \mathrm{d}$ of MP has been suggested for mammary growth (Bell et al., 2000); however, needs for mammary tissue accretion are not currently included in the NRC (2001) model. Nulliparous cows typically calve at 85 to $90 \%$ of mature BW and, therefore, they have AA needs for additional growth, which results in extra requirements for lean tissue accretion during late gestation. An increased protein requirement for lean tissue and mammary accretion coupled with potential depression in DMI of cows in the last weeks of gestation (Hayirli et al., 2002) might result in potential benefits of feeding diets with increased CP content (Bell et al., 2000). Feeding more protein to late-gestation primigravid cows to increase maternal reserves at calving may provide potential for mobilization of tissue AA to contribute to yields of milk (Adachi et al., 2006) and milk protein in the subsequent early lactation (van Saun et al., 1993). However, Komaragiri and Erdman (1997) demonstrated that although transition dairy cows mobilize body protein, more than $90 \%$ of the energy mobilized in early lactation is associated with changes in body fat, whereas protein accounts for only $7 \%$ of the energy lost or gained in this period.

Bell et al. (2000) reviewed the literature and concluded that the benefits of increasing dietary protein were observed when the control treatment diet had less than $12 \% \mathrm{CP}$ or supplied a limited amount of RUP. Ideally, diet formulation would be based on supply of individual AA; however, few experiments manipulated specific AA with rumen-protected sources only during the prepartum period. An initial step to address this issue is to use the current literature with experiments in which dietary $\mathrm{CP}$ was manipulated and estimate the supply of MP using a common platform in an attempt to estimate the protein supply that optimizes lactation performance. The supply of specific AA can then be derived using nutrition models, although the predicted supply will likely differ with the software used.

The hypothesis of the present study was that postpartum production performance in dairy cows is influenced by the content of protein fed in diets prepartum. In particular, we hypothesized that responses to prepartum dietary protein would differ according to parity group, and increasing dietary protein would benefit nulliparous more than parous cows because of needs for growth and less DMI. Therefore, the objectives of the study were to use data from the published literature from experiments in which dietary protein fed prepartum was manipulated and evaluate the effects on production performance. A second objective was to use estimates of MP supply using the NRC (2001) that optimizes postpartum performance as an empirical method to establish the needs for MP in prepartum diets.

\section{MATERIALS AND METHODS}

\section{Search of the Published Literature}

A comprehensive search of the literature published in the English language from 1984 to 2017 was conducted to identify experiments with transition dairy cows fed prepartum diets in which the content or degradability of protein was manipulated prepartum or diets that were supplemented with AA only prepartum. Experiments in which rumen-protected AA were supplemented preand postpartum were excluded because of the inability to differentiate an effect of pre- or postpartum supplementation. Responses of interest included prepartum DMI, BW, and BCS, and postpartum DMI, yields of milk and milk components, BW, BCS, and energy balance.

The literature search was carried out using 2 search engines, the US National Library of Medicine National Institutes of Health through PubMed (http://www .ncbi.nlm.nih.gov/pubmed) and the ISI Web of Science (http://apps.webofknowledge.com). In addition, we searched the proceedings of the joint annual meeting of the American Dairy Science Association (https:// www.adsa.org/) and American Society of Animal Science (https://www.asas.org/), a database of theses and dissertations (http://www.proquest.com/), and the websites of animal nutrition journals (http://www .publish.csiro.au/). The search was conducted between January 2016 and August 2017 using the terms with a set of 3 keywords in all searches: cow or protein or prepartum; cow or rumen undegraded protein or prepartum; cow or rumen undegradable protein or prepartum; and cow or AA or prepartum. The search aimed to identify publications with experiments that were suitable for further exploration. Whenever a citation in a manuscript identified a reference not listed in the searched database, that publication was investigated. Additional requests were made to individual authors 
of manuscripts to identify data that might have been collected but not reported in the published manuscript. Authors of scientific abstracts were contacted to have access to the complete set of responses that might have not been presented in the abstract.

\section{Inclusion and Exclusion Criteria}

The initial criteria for including experiments in the meta-analysis were manipulations of either the content or degradability of protein fed to prepartum cows or supplementation with rumen-protected AA only during the prepartum period. Experiments had to be either completely randomized designs or randomized block designs. Dietary interventions had to be described relative to the ingredient composition of the prepartum diets and the chemical analyses describing the $\mathrm{CP}$, ash, NDF, and crude fat. All diets were entered with respective chemical analysis of ingredients, whenever available, into the NRC (2001) software. Information about cow parity, BW, and DMI were used for each treatment diet to estimate the contents of $\mathrm{NE}_{\mathrm{L}}, \mathrm{RDP}, \mathrm{RUP}$, and predicted supplies of MP and EAA. Whenever the chemical composition of individual ingredients was not available, the NRC (2001) library was used to match as closely as possible the final chemical composition of the TMR as described in the experiment. When the nutrient composition of the diet entered in the NRC model differed from the composition reported in the original paper, the composition of each ingredient (OM, CP, $\mathrm{NDF}, \mathrm{ADF}$, and ether extract) from the NRC library was adjusted using a correction factor. The correction factor was calculated as the ratio of the nutrient in the NRC-built diet to that reported for the TMR in the respective experiment. This coefficient was applied to all ingredients so that the NRC-built TMR nutrient estimates approximated those actually fed to cows in the experiment. Diets were offered for ad libitum intake in all experiments except for Robinson et al. (2001, 2004), which limited the amounts of DM offered to 12 to $14 \mathrm{~kg} / \mathrm{cow}$ per day.

The searched literature was screened for duplicates and then suitability for inclusion was evaluated by initially reading the abstract to ensure that the experiment was conducted with prepartum dairy cows and that diets were manipulated accordingly. Then, the materials and methods portion of the manuscript was read to exclude experiments in which treatments were not implemented as previously described or when descriptions of diets were not available. After the initial search and screening, 48 publications including multiple experiments were assessed for eligibility. Of those, 21 publications were excluded for the following reasons: re- sponses of interest were not reported in the manuscript (4 experiments), treatments were infused and not fed as diets (1 experiment), treatments were applied pre- and postpartum or postpartum only (10 experiments), cows were fed component-fed diets and the total nutrient intake was unclear (1 experiment), mineral and fatty acid manipulation (2 experiments), cows fed the same prepartum diet (1 experiment), or review of data from literature or meta-analysis (2 publications). Figure 1 depicts a PRISMA diagram (Moher et al., 2009) of the flow of data collection for the meta-analysis.

\section{Experiments Included}

A total of 27 experiments with up to 125 treatment means, depending on the response variable, were included in the meta-analysis. Means were not available for all responses evaluated in all 27 experiments, and details of the number of means included in each analysis are provided elsewhere in the manuscript. A list of the experiments included in the meta-analysis is depicted in Table 1.

\section{Data Extraction}

Experiments had to report individual treatment least squares means (LSM) and standard errors of the means (SEM) that were extracted from tables or figures. Values presented in figures were extracted using image extraction software (https://automeris.io/ WebPlotDigitizer/). Two known data sets were initially used to ensure that the software recovered accurate values of LSM and SEM from figures.

Data collected for each treatment within experiment included number of cows, parity group prepartum as nulliparous (lactation 0 prepartum, lactation 1 postpartum) or parous cows (lactation $>0$ prepartum, multiparous postpartum), ingredient composition of diets fed prepartum, and the nutrient content of ingredients or diets fed prepartum. Responses collected for the prepartum period included DMI, BW, and BCS; information on BW change and energy balance were not considered for statistical analyses because only a few experiments reported those data and, therefore, the SEM were only available for a limited number of treatment means. Responses collected for the postpartum period included DMI, yields of milk and FCM, concentrations and yields of fat and protein in milk, BW, BW change, BCS, and BCS change. Only a few experiments reported energy balance postpartum and, thus, it was not considered for statistical analysis. Throughout the manuscript, parity group is defined based on lactation number prepartum as nulliparous (lactation 0 pre- 


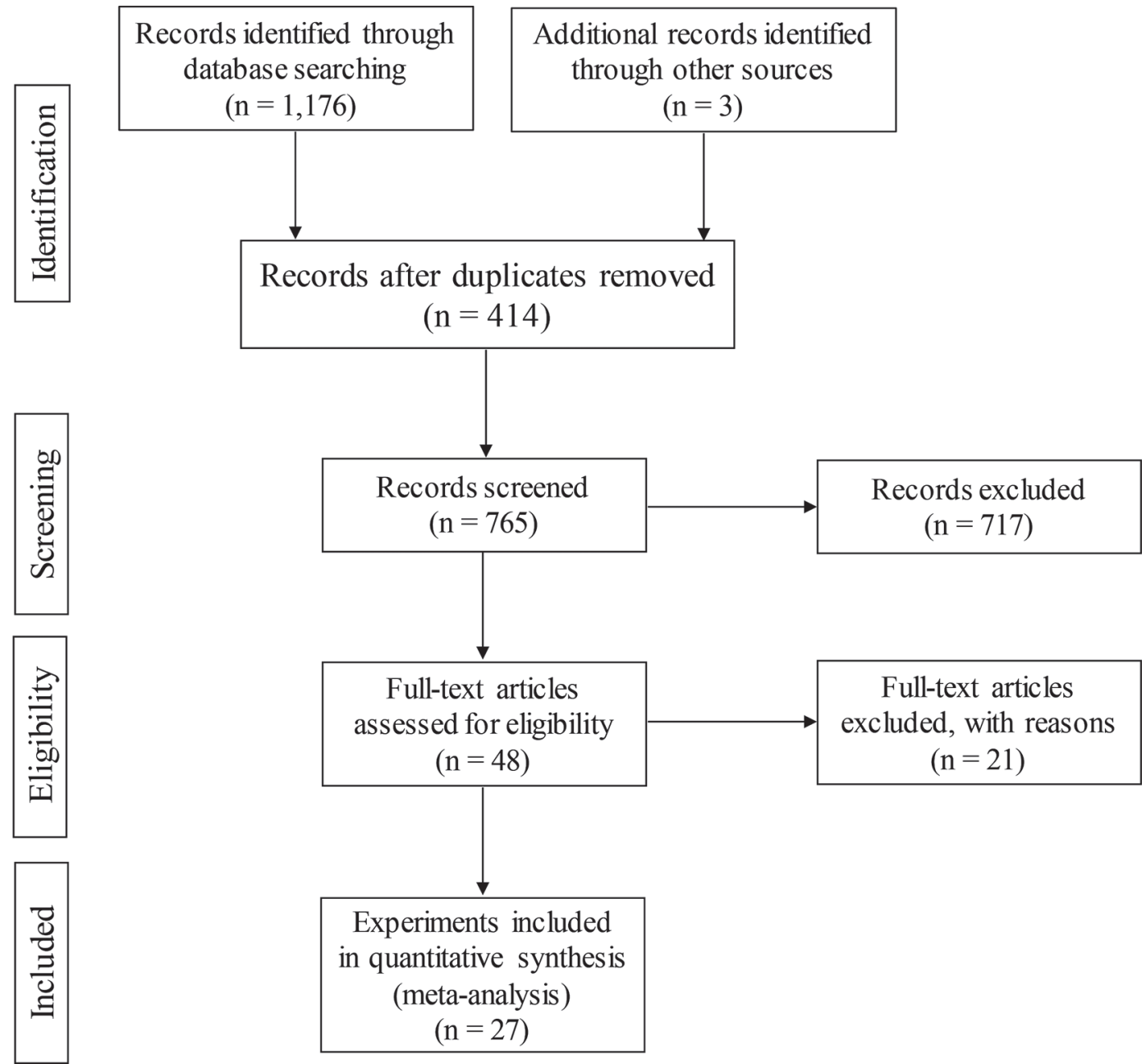

Figure 1. PRISMA (Preferred Reporting Items for Systematic Reviews and Meta-Analyses) flow diagram of the systematic review from initial search and screening to final selection of publications to be included in the meta-analysis. The 27 articles selected for inclusion in the meta-analysis each contained a single experiment; therefore, 27 experiments were used.

partum and primiparous postpartum) or parous cows (lactation $>0$ prepartum, multiparous postpartum). Three experiments reported data for nulliparous and parous together. Because parous cows represented the majority of cows in those 3 experiments $(75,75$, and $60 \%$ ), parity group was considered parous (Table 1 ). The information on days fed the prepartum diets was collected but not considered in the statistical models. This was because in all experiments except one, the exposure to prepartum diets was identical between different treatments within an experiment; therefore, no within-experiment variation could be modeled in the statistical analyses.

Data were transferred to Excel spreadsheets (Microsoft Corp., Redmond, WA) and reviewed by 2 people multiple times to ensure that the information collected was accurately transcribed from the manuscripts into the spreadsheets before statistical analyses.

\section{Statistical Analysis}

Data were analyzed by the MIXED procedure of SAS (ver. 9.4, SAS Institute Inc., Cary, NC). Data were analyzed using either dietary $\mathrm{CP}$ as the key predictor of interest or the predicted supply of MP as the key predictor of interest.

Continuous variables were analyzed using the MIXED procedure of SAS with estimations carried out by the REML method. All mixed models included the random effect of experiment, and responses were weighted using the WEIGHT statement in SAS with the inverse of the squared value of the SEM $\left(1 / \mathrm{SEM}^{2}\right)$ that was centered 


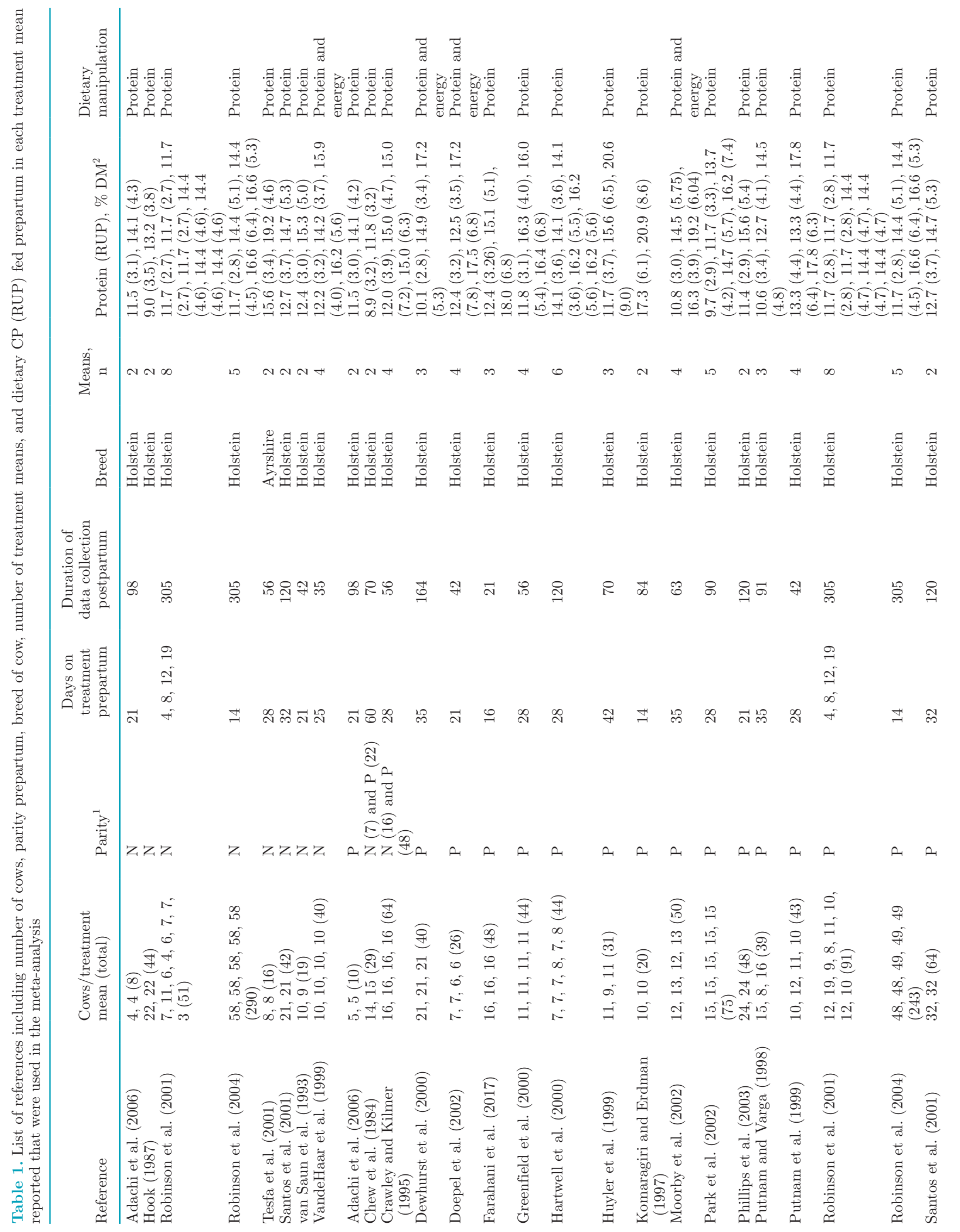




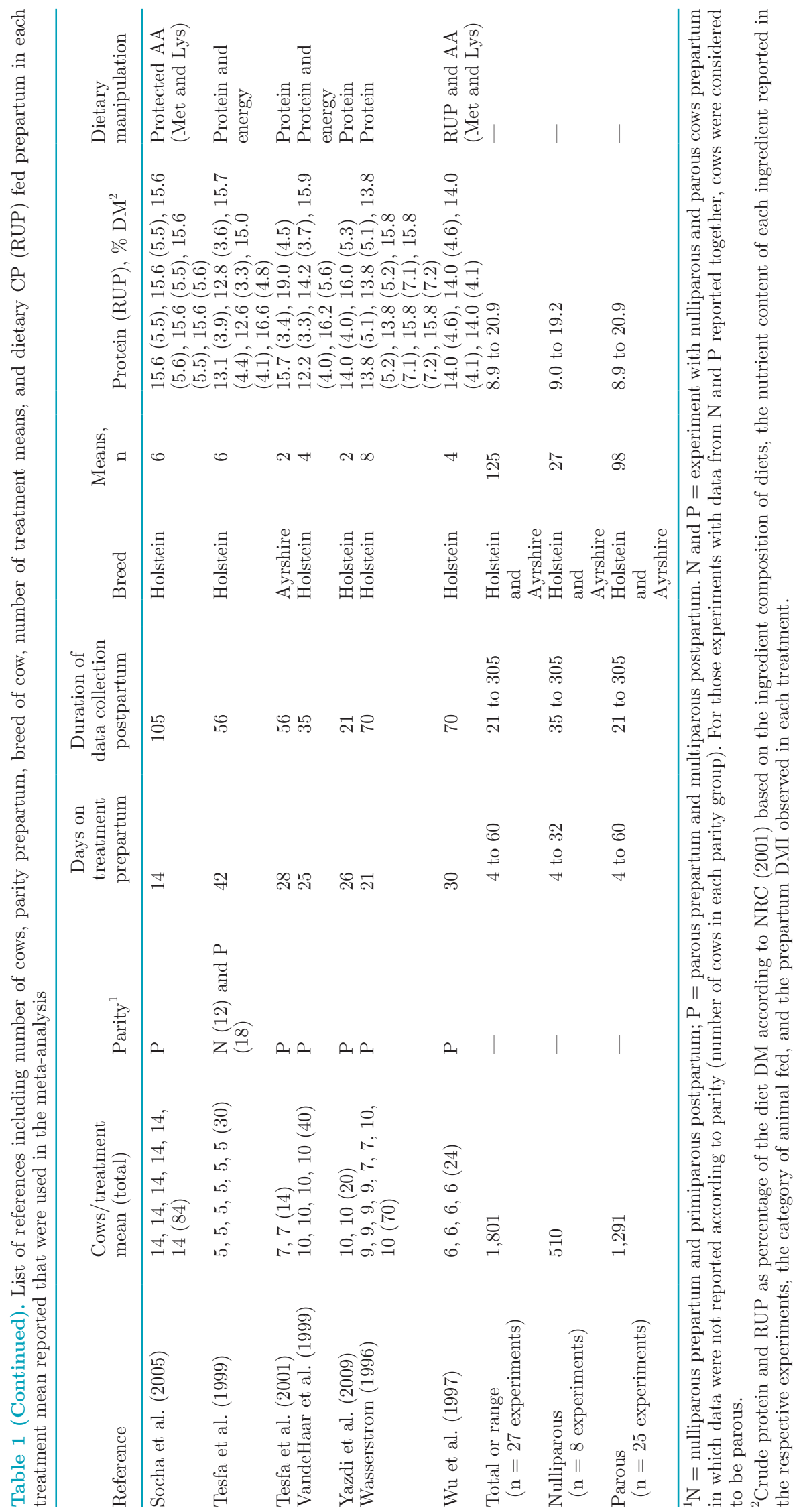


for each response analyzed, as suggested by Wang and Bushman (1999). Statistical models were built following the general matrix notation of a mixed model:

$$
y=\mathbf{X} \boldsymbol{\beta}+\mathbf{Z}_{\boldsymbol{\gamma}}+\varepsilon,
$$

where $y$ is the response analyzed, $\mathbf{X}$ is the design matrix corresponding to the fixed effects and the associated vector $\boldsymbol{\beta}$ of the regression coefficients, $\mathbf{Z}$ is the matrix for the random effects with the vector $\gamma$ of their associated coefficients; and $\varepsilon$ is the random error assumed to be normally distributed with mean 0 and homogeneous variance.

For the models considering $\mathrm{CP}$ as the predictor of interest, the parameters considered for the statistical models included prepartum dietary CP content (\% of $\mathrm{DM}$ ), parity prepartum (nulliparous or parous), prepartum dietary $\mathrm{NE}_{\mathrm{L}}$ content $(\mathrm{Mcal} / \mathrm{kg}$ ), and the centered value of each experiment mean $\mathrm{CP}$ relative to the mean $\mathrm{CP}$ value of all experiments. Predictors were first inspected for multicollinearity for every response analyzed using collinearity analysis (Collin) in the REG procedure of SAS and inspecting condition index, tolerance, and variance inflation factor (VIF). For all responses evaluated, there was no indication of multicollinearity based on condition index $<25$ and VIF $<2.0$.

Univariable analyses including a single fixed effect and the random effect of experiment were performed to understand the association between each predictor and the response analyzed. Subsequently, for all responses analyzed, multivariable mixed models were built that included the random effect of experiment and the linear effect of prepartum dietary CP content (\% of DM), the linear effect of the experiment centered value of prepartum dietary CP, parity group (nulliparous vs. parous), prepartum dietary $\mathrm{NE}_{\mathrm{L}}$ content (Mcal/kg of $\mathrm{DM}$ ), the quadratic effect of prepartum dietary $\mathrm{CP}$ content ( $\%$ of $\mathrm{DM})$, and the interactions between prepartum dietary $\mathrm{CP}$ and the experiment centered value of prepartum dietary $\mathrm{CP}$, prepartum dietary $\mathrm{CP}$ and parity, and the quadratic effect of prepartum dietary $\mathrm{CP}$ and parity. After building the multivariable models, a backward stepwise elimination procedure was applied and parameters were removed sequentially based on the highest $P$-value for those with $P>0.10$. For explanatory variables in which the individual parameter and the interaction resulted in $P>0.10$, the interaction term was first removed and the model rerun before each component of the interaction could be removed if the $P$-value remained larger than 0.10 . Each model was rerun until interactions or individual parameters resulted in $P \leq 0.10$. The final models included at least the following forced parameters: the linear effect of prepartum dietary $\mathrm{CP}$, the linear effect of the experiment centered value of prepartum dietary $\mathrm{CP}$, parity, prepartum dietary $\mathrm{NE}_{\mathrm{L}}$ content predicted from NRC (2001), and the interaction between prepartum dietary $\mathrm{CP}$ and parity. At each iteration, VIF and distribution of residuals and homogeneity of variance were inspected to avoid collinearity and to certify that data fit the assumptions of normality. Briefly, plots were visually inspected for the distribution of residuals and it was accepted that assumptions of normality were not infringed upon when at least $95 \%$ of the studentized residuals were within \pm 2 SD. The INFLUENCE statement in SAS was used to determine potential influential points with high leverage or large Cook's D. Goodness-of-fit statistics for distribution of residuals were evaluated in all analyses. Whenever the null hypothesis was rejected $(P<0.05)$, then the Box-Cox power transformation was used to determine the proper transformation of data before statistical analyses (Piepho, 2009). If final models were the same and significance and interpretation of the data did not change with transformation, then the analysis was carried out on the original scale of the data. Once the final model was obtained, variance inflation was reassessed to ensure that factors remaining in the model resulted in low VIF, and distribution of residuals and homogeneity of variance were evaluated as previously described. Subsequently, the random slope of prepartum dietary CP content was evaluated using an unstructured variance-covariance structure. Only the random slope of dietary $\mathrm{CP}$ was evaluated because the models did not converge when more than one independent variable was analyzed with random slopes. If the random slope of dietary $\mathrm{CP}$ was not significant $(P>$ $0.10)$, then it was removed from the final model. If the interaction between dietary $\mathrm{CP}$ and parity was significant $(P<0.10)$, then separate analyses were performed for each parity (nulliparous or parous cows) using the same final model excluding parity and interactions with parity.

Data were also analyzed using the same methodology described previously but with MP as the predictor in place of dietary $\mathrm{CP}$; however, because the predicted supplies of MP resulted in substantially distinct ranges in nulliparous (517 to $1,094 \mathrm{~g} / \mathrm{d}$ ) and parous cows (463 to $1,733 \mathrm{~g} / \mathrm{d}$ ), data were analyzed separately for each parity group to be able to investigate linear and quadratic effects of MP within the range of predicted supplies for each parity group. The fixed effects considered for the statistical models included predicted supply of MP prepartum (g/d) obtained from NRC (2001), prepartum dietary $\mathrm{NE}_{\mathrm{L}}$ content $(\mathrm{Mcal} / \mathrm{kg}$ ) predicted from NRC (2001), and the centered value of prepartum predicted supply of MP relative to the mean value of 
all experiments within parity group. Predictors were inspected for multicollinearity. The initial multivariable model included the linear effect of predicted supply of MP, the linear effect of the experiment centered value of predicted supply of MP, prepartum dietary $\mathrm{NE}_{\mathrm{L}}$ content, the quadratic effect of the predicted supply of $\mathrm{MP}$, and the interaction between the predicted supply of MP and the centered value of the supply of MP prepartum. The final models retained the significant fixed effects based on $P \leq 0.10$, and the linear effect of predicted supply of MP prepartum and experiment centered value of prepartum supply of MP within parity group were always included as forced parameters regardless of significance. For parous cows, 2 distinct groups of experiments were observed: 4 experiments with cows producing $<28 \mathrm{~kg}$ of milk/d (15 treatment means) and another 21 experiments with cows producing $>36 \mathrm{~kg}$ of milk/d (83 treatment means). Two categories were created based on level of milk production, one representing the experiments with milk production $<28 \mathrm{~kg} / \mathrm{d}$ and one for those with $>36 \mathrm{~kg} / \mathrm{d}$. The effects of level of milk production and the interaction between the predicted supply of MP and level of milk production were also included in the multivariable models for parous cows. A backward elimination procedure was applied as described for the models with CP as predictor.

Figures were generated with predicted responses for each treatment mean contributing data for the analysis of the specific response according to prepartum parity and based on the random (best linear unbiased prediction) and fixed (best linear unbiased estimates) effects from the mixed models and the weighting with the inverse of the SEM squared. Fitted values with best linear unbiased estimates to altering the prepartum dietary CP from 12 to $15 \%$ of DM and to altering the supply of MP from 800 to 1,000 and from 900 to $1,200 \mathrm{~g} / \mathrm{d}$ were computed for nulliparous and parous cows, respectively. The reason for those values was to represent concentrations of dietary CP or supply of MP that would typically be recommended to prepartum dairy cows. For those results, the final statistical models were used and they assumed that cows were fed prepartum diets using the mean value for dietary $\mathrm{NE}_{\mathrm{L}}$ content $(1.59 \mathrm{Mcal} / \mathrm{kg})$. Whenever the linear or quadratic effect of the predictor (CP content or predicted supply of MP) was significant $(P<0.10)$, then the best-fit line predicted from the final model was included in the figures.

Statistical significance was considered at $P \leq 0.05$, and tendency was considered at $0.05<P \leq 0.10$.

\section{RESULTS}

The number of experiments reporting data for nulliparous separately from parous cows was only 8 , with a total of 510 cows and a range of prepartum CP fed from 9.0 to $19.2 \%$ of DM (Tables 1 and 2). Twenty-five experiments reported data for parous cows, resulting

Table 2. Descriptive statistics of the energy and protein content of diets offered to prepartum cows and intake of protein and flow AA in nulliparous and parous cows ${ }^{1}$

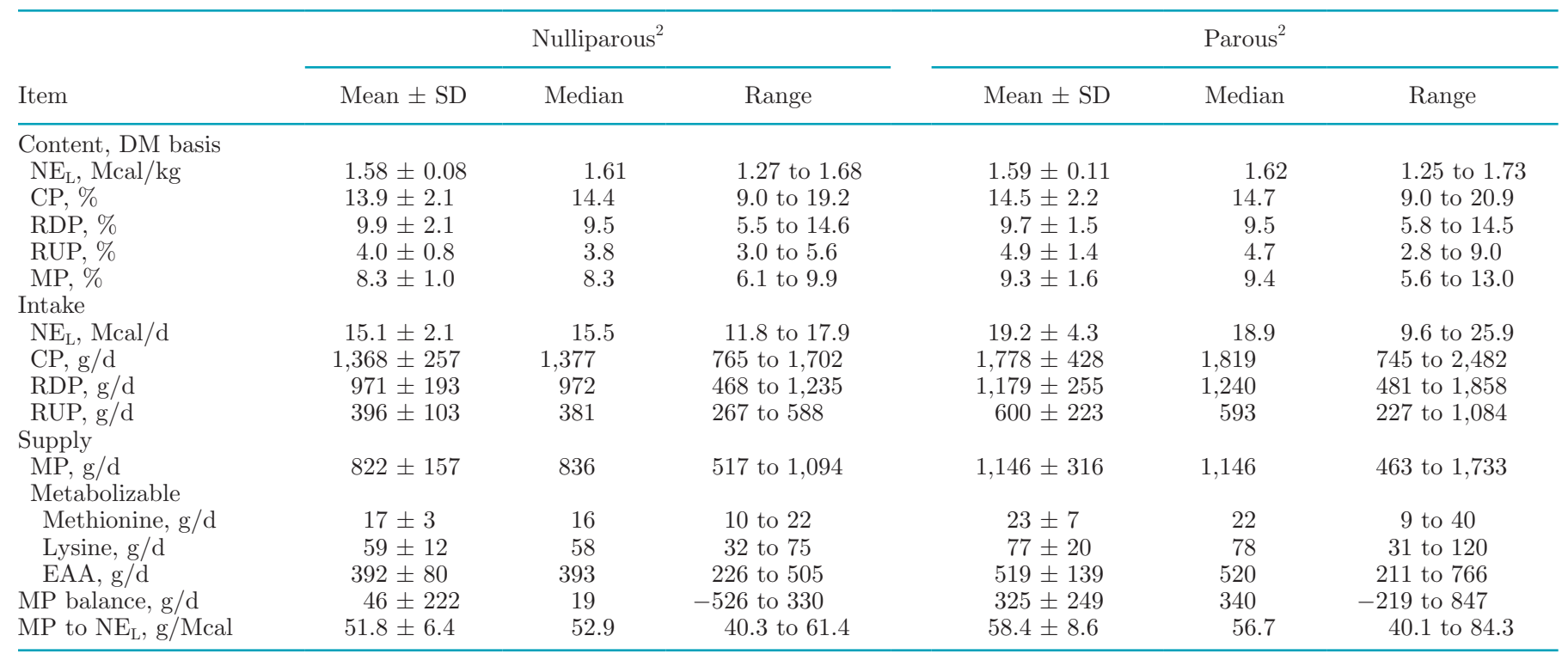

${ }^{1}$ Predicted contents of RDP, RUP, MP, and $\mathrm{NE}_{\mathrm{L}}$ and supplies of MP and metabolizable AA calculated using NRC (2001) and according to composition of diets for each treatment mean and respective DMI.

${ }^{2}$ Nulliparous $=$ nulliparous prepartum and primiparous postpartum; Parous $=$ parous prepartum and multiparous postpartum. Cows from experiments including nulliparous and parous cows prepartum in which data were not reported according to parity were considered to be parous cows. 
META-ANALYSIS OF PREPARTUM PROTEIN

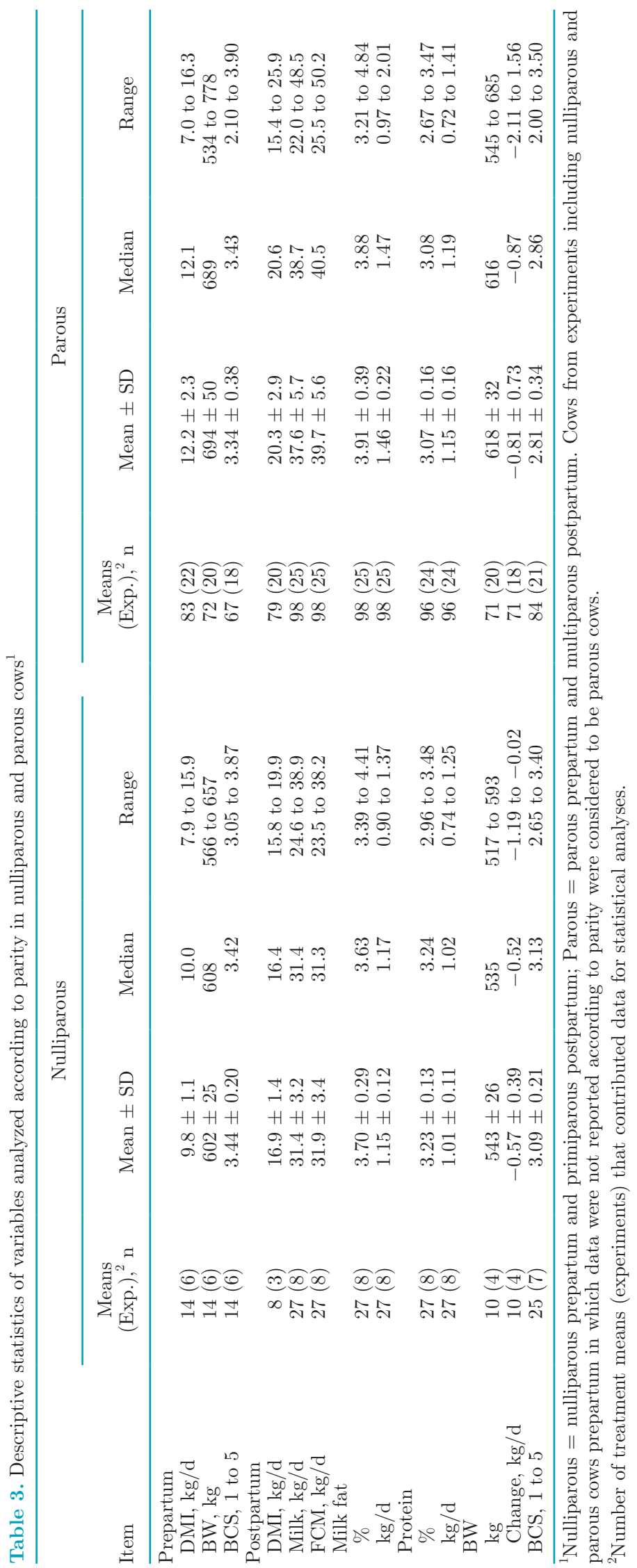




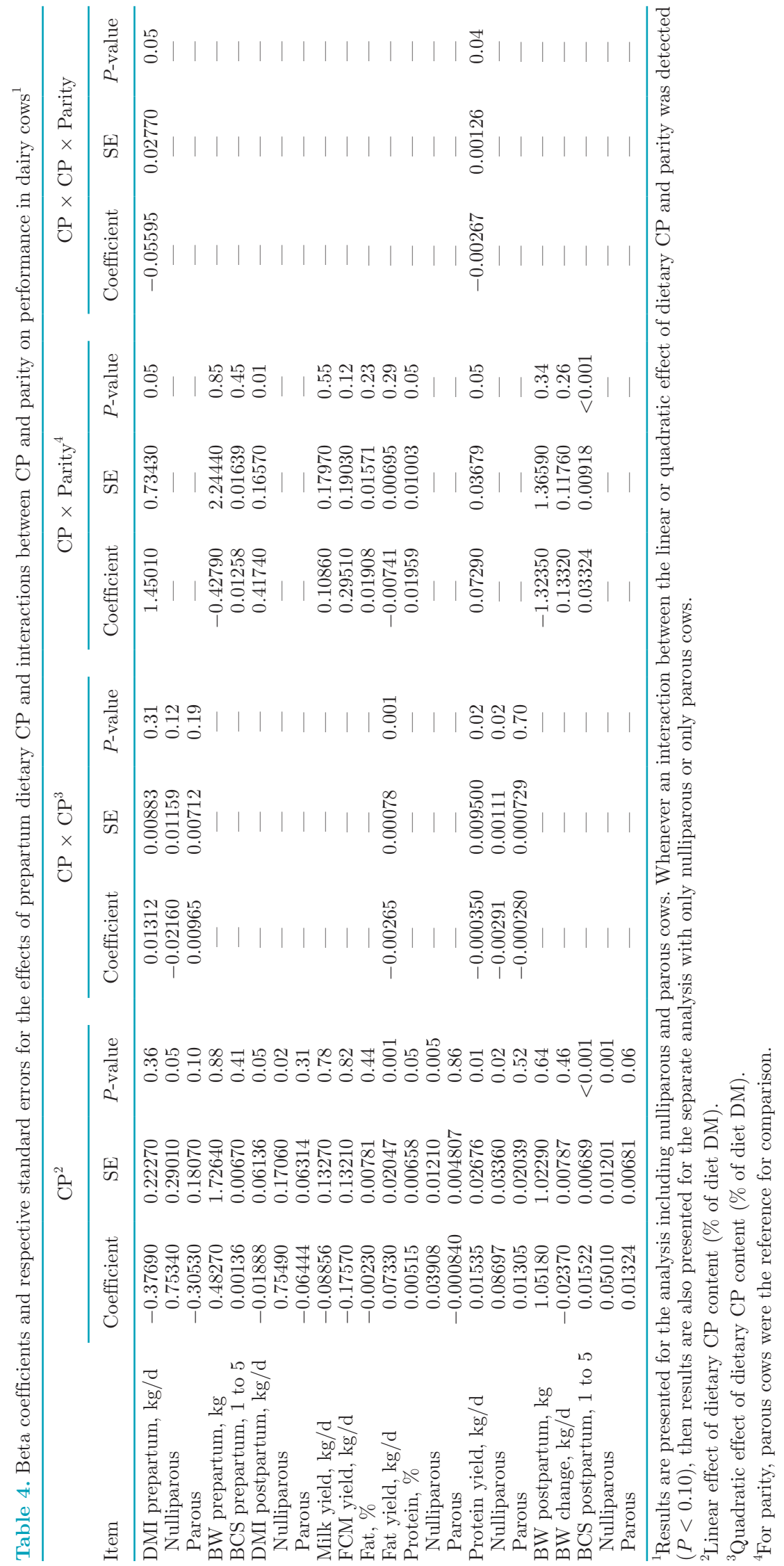


META-ANALYSIS OF PREPARTUM PROTEIN

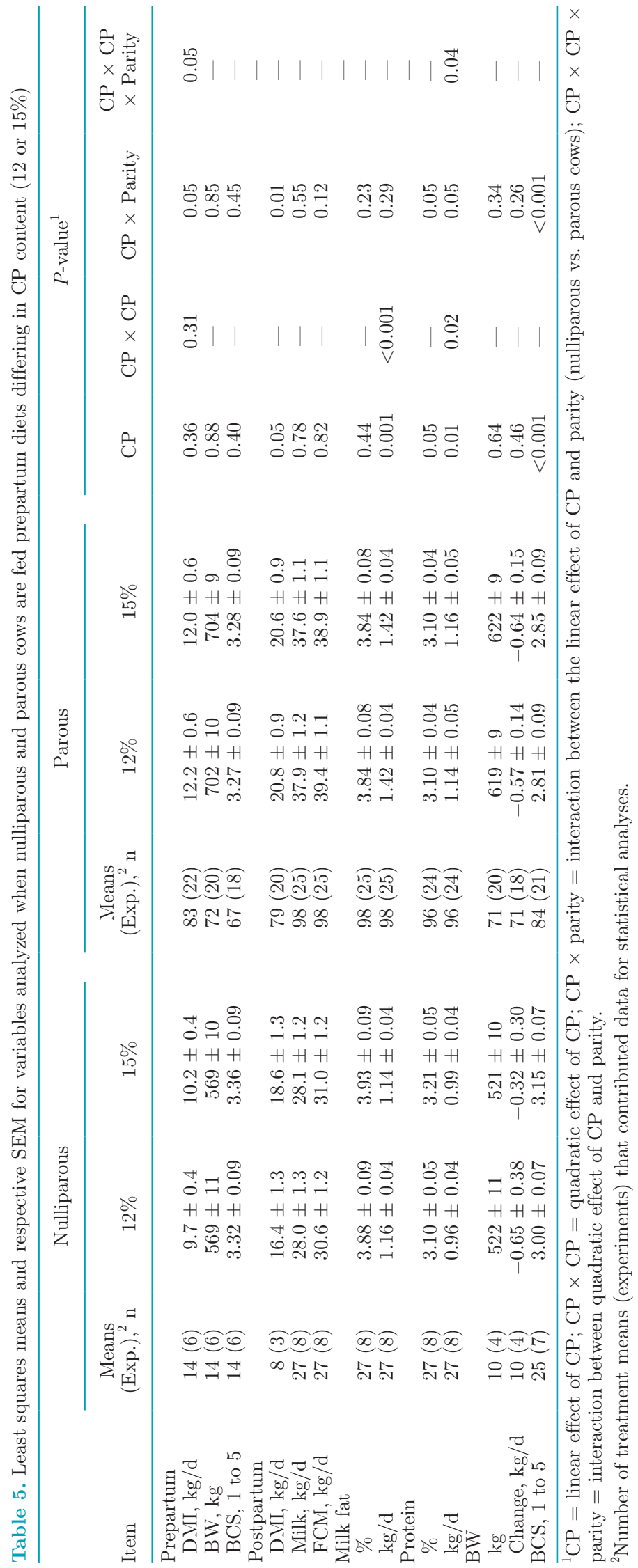



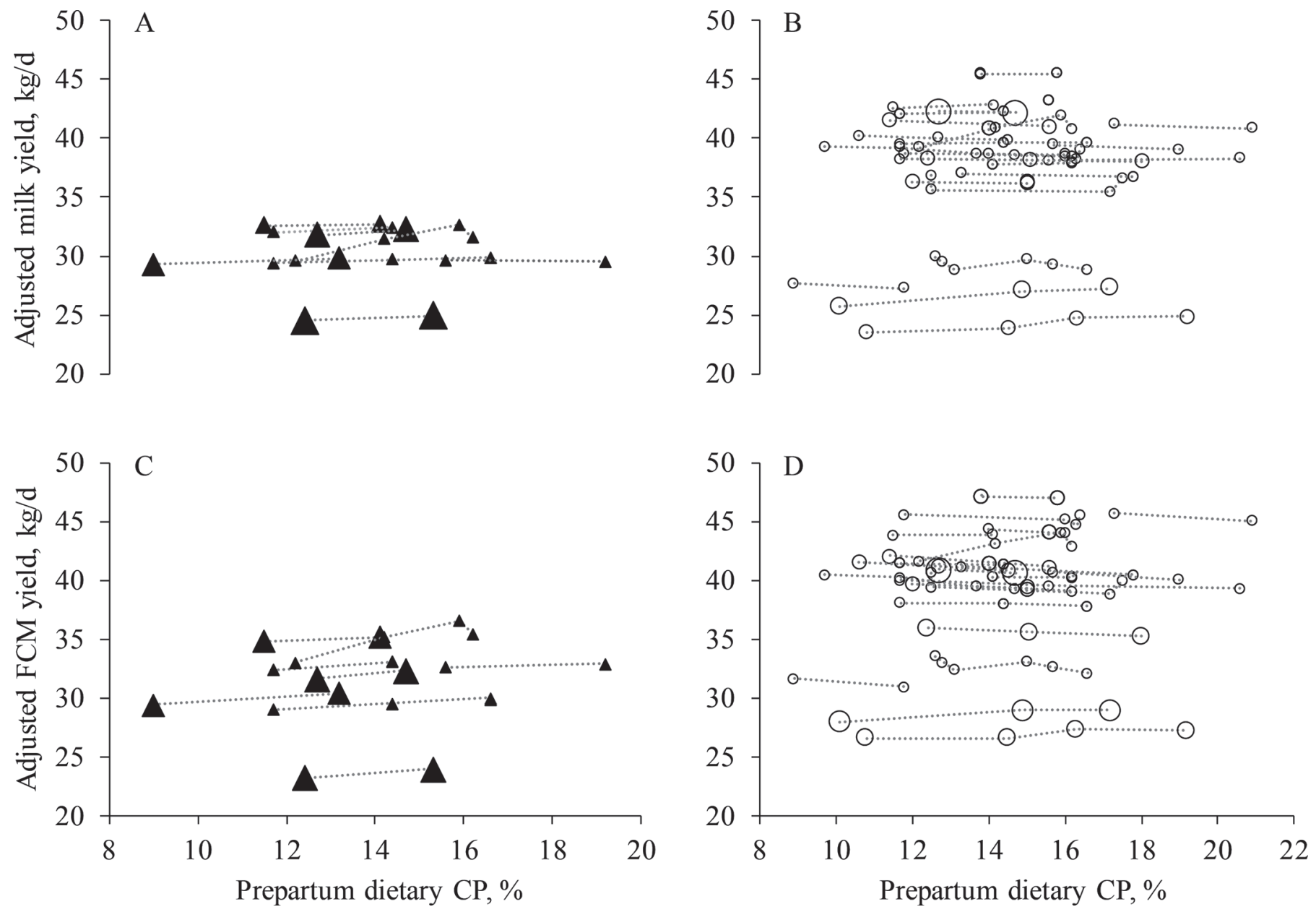

Figure 2. Postpartum performance in nulliparous $(\boldsymbol{\Lambda})$ and parous $(\bigcirc)$ cows according to level of prepartum dietary CP. Dotted lines connect predicted values within experiment. Milk yield (A and B): linear effect of prepartum dietary $\mathrm{CP}(P=0.78)$, quadratic effect of prepartum dietary $\mathrm{CP}(P=0.77)$, and interactions between the linear effect of $\mathrm{CP}$ and parity $(P=0.55)$, and the quadratic effect of CP and parity $(P$ $=0.69)$. Fat-corrected milk yield $(\mathrm{C}$ and $\mathrm{D})$ : linear effect of prepartum dietary $\mathrm{CP}(P=0.82)$, quadratic effect of prepartum dietary $\mathrm{CP}(P=$ $0.80)$, and interactions between the linear effect of $\mathrm{CP}$ and parity $(P=0.12)$, and the quadratic effect of $\mathrm{CP}$ and parity $(P=0.64)$. Nulliparous cows: lactation 0 prepartum and lactation 1 postpartum; Parous cows: lactation $>0$ prepartum. (A) 8 experiments and 27 treatment means; (B) $=25$ experiments and 98 treatment means; (C) 8 experiments and 27 treatment means; (D) 25 experiments and 98 treatment means. The size of the symbols represents the weight of treatment mean in the analysis.

in 1,291 cows fed diets with a wider range of $\mathrm{CP}$ prepartum, from 9.0 to $20.9 \%$ of DM (Tables 1 and 2). Descriptive statistics of the $\mathrm{NE}_{\mathrm{L}}$ content and protein composition of prepartum diets and intake of energy and protein by cows according to parity group are presented in Table 2. Duration of prepartum feeding of diets reported in the experiments averaged $( \pm \mathrm{SD}) 22.2$ \pm 15.8 and $25.9 \pm 10.3 \mathrm{~d}$ for nulliparous and parous cows, respectively. Descriptive statistics including the number of treatment means reported for production performance according to parity group is presented in Table 3 . The relationships between dietary $\mathrm{CP}$ content and predicted supplies of MP, total metabolizable EAA, and metabolizable methionine and lysine are presented in Supplemental Figure S1 (https://doi.org/10.3168/ jds.2018-16043).

\section{Effect of Prepartum Dietary CP on Prepartum Performance}

A total of 97 treatment means from 24 experiments reported DMI prepartum (Table 3$)$. An interaction $(P$ $=0.05)$ between the quadratic effect of prepartum CP and parity was observed for prepartum DMI because for nulliparous animals, increasing dietary CP increased $(P=0.05)$ prepartum intake, whereas for parous cows, increasing dietary $\mathrm{CP}$ tended $(P=0.10)$ to decrease prepartum intake (Table 4$)$. Increasing prepartum di- 
etary CP from 12 to $15 \%$ of the diet DM predicted an increase of 0.5 and a decrease of $0.2 \mathrm{~kg}$ of $\mathrm{DMI} / \mathrm{d}$ in nulliparous and parous cows, respectively (Table 5). Body weight and BCS prepartum were not influenced by prepartum dietary $\mathrm{CP}$ or by the interaction between dietary protein and parity group. The beta coefficients and respective standard errors for predictors retained in the final models for the effects of prepartum dietary $\mathrm{CP}$ on prepartum performance in dairy cows are presented in Supplemental Table S1 (https://doi.org/10 .3168/jds.2018-16043).
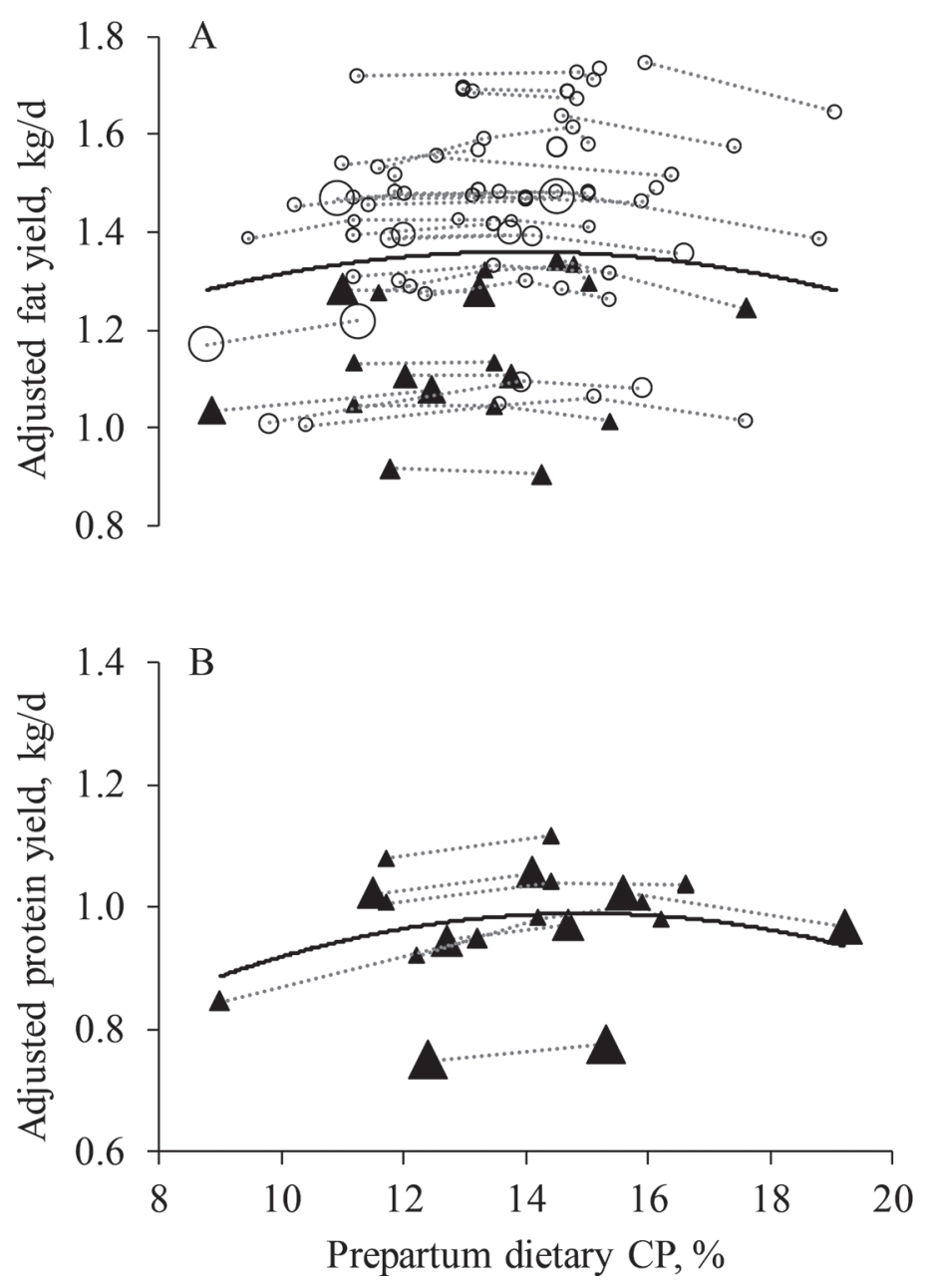

\section{Effect of Prepartum Dietary CP on Postpartum Performance}

Postpartum DMI was reported in 20 experiments with 87 treatment means; however, only 3 of those experiments with 8 treatment means reported data separately for nulliparous cows (Table 3). An interaction $(P=0.01)$ between the linear effect of prepartum $\mathrm{CP}$ and parity was observed for intake postpartum (Table 4). Increasing prepartum dietary CP increased $(P=0.02)$ postpartum DMI in nulliparous animals but

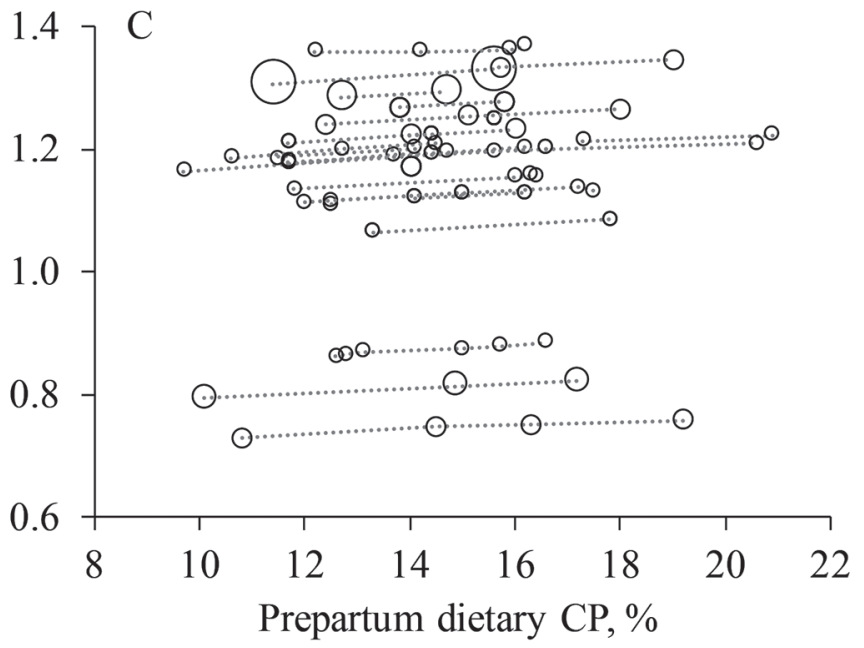

Figure 3. Postpartum performance in nulliparous $(\boldsymbol{\Delta})$ and parous $(\bigcirc)$ cows according to level of prepartum dietary CP. Dotted lines connect predicted values within experiment. Continuous line, presented only when statistical significance was observed, depicts the response to level of prepartum dietary CP. Fat yield $(\mathrm{A})$ : linear effect of prepartum dietary $\mathrm{CP}(P=0.001)$, quadratic effect of prepartum dietary CP $(P<0.001)$, and interactions between the linear effect of $\mathrm{CP}$ and parity $(P=0.29)$, and the quadratic effect of CP and parity $(P=0.35)$. For protein yield, because of interactions between the linear effect of $\mathrm{CP}$ and parity $(P=0.05)$, and the quadratic effect of $\mathrm{CP}$ and parity $(P=0.04)$, analyses were performed separately for each parity group. Protein yield nulliparous $(\mathrm{B})$ : linear effect of prepartum dietary CP $(P=0.02)$, quadratic effect of prepartum dietary CP $(P=0.02)$. Protein yield parous $(\mathrm{C})$ : linear effect of prepartum dietary CP $(P=0.52)$, quadratic effect of prepartum dietary CP $(P=0.70)$. Nulliparous cows: lactation 0 prepartum and lactation 1 postpartum; Parous cows: lactation $>0$ prepartum. (A) 27 experiments and 125 treatment means; $(\mathrm{B})=8$ experiments and 27 treatment means; (C) 24 experiments and 96 treatment means. The size of the symbols represents the weight of treatment mean in the analysis. 
Table 6. Beta coefficients and respective standard errors for the effects of altering the predicted dietary supply of MP prepartum on performance in dairy cows ${ }^{1}$

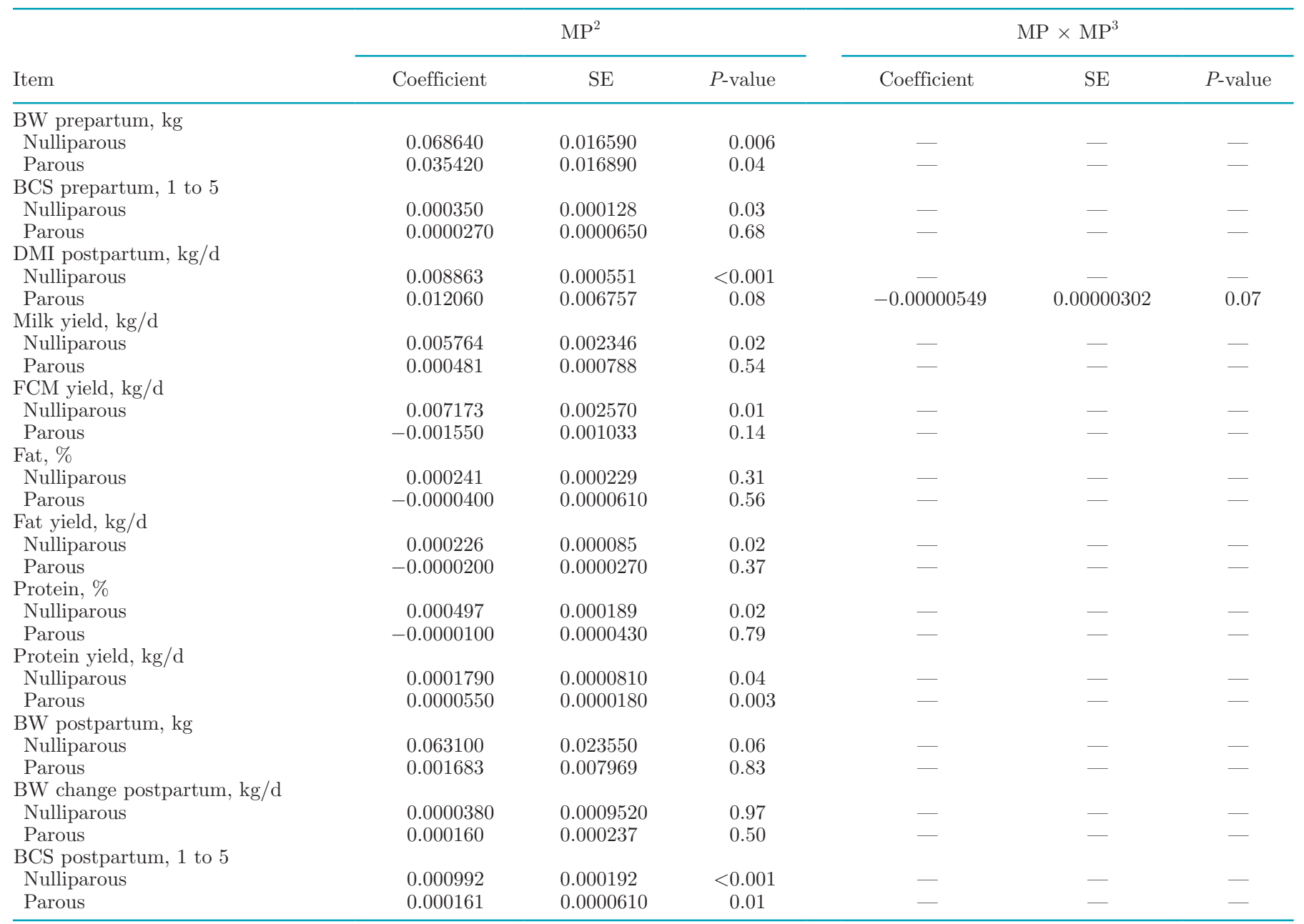

${ }^{1}$ The MP supply was predicted using NRC (2001) according to the diet composition and the mean DMI prepartum for the respective treatment and cow characteristics prepartum (lactation number, mean BW, and mean BCS). Data were analyzed separately for nulliparous and parous cows.

${ }^{2}$ Linear effect of predicted supply of MP (g/d).

${ }^{3}$ Quadratic effect of predicted supply of MP $(\mathrm{g} / \mathrm{d})$.

had no effect on intake of parous cows. An increase of approximately $2.2 \mathrm{~kg} / \mathrm{d}$ in DMI was estimated by increasing prepartum dietary CP from 12 to $15 \%$ of DM in nulliparous cows, whereas the intake of parous cows with the dietary manipulation remained unchanged (Table 5).

Yields of milk, FCM, and milk fat, and concentration of milk fat were reported in 27 experiments with 125 treatment means. Of those, 8 experiments with 27 treatment means reported data separately for nulliparous cows (Table 3). Prepartum dietary CP did not affect milk yield, which averaged $28.1 \pm 1.2$ and $37.8 \pm$ $1.2 \mathrm{~kg} / \mathrm{d}$ in nulliparous and parous cows, respectively (Figures 2A and 2B, and Table 4). Similarly, yield of
FCM (Figures 2C and 2D) and concentration of fat in milk were not influenced by prepartum dietary $\mathrm{CP}$ (Table 4). Nevertheless, fat yield responded quadratically $(P<0.001)$ to prepartum dietary protein content (Figures 3A, and Table 4). The quadratic effect of CP on fat yield was maximized at $14 \%$ of diet DM, when nulliparous and parous cows produced 1.15 and 1.42 $\mathrm{kg}$ of milk fat/d, respectively (Figure 3A and Table $5)$. Yield and concentration of protein in milk were reported in 26 experiments with 123 treatment means, of which 8 experiments with 27 treatment means reported data separately for nulliparous cows (Table $3)$. An interaction $(P=0.05)$ between linear effect of $\mathrm{CP}$ and parity was observed for milk protein content 
META-ANALYSIS OF PREPARTUM PROTEIN

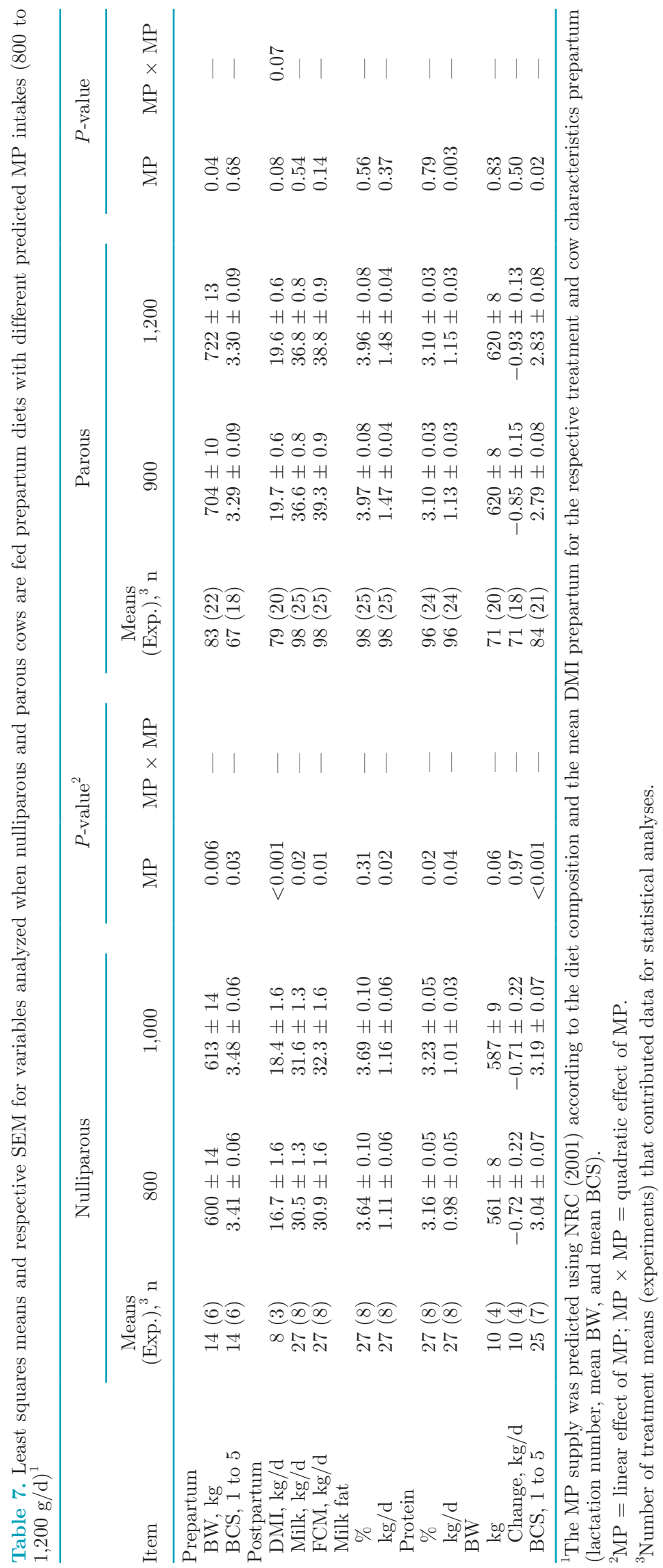


(Table 4). Increasing prepartum CP content increased $(P=0.005)$ the concentration of protein in milk of nulliparous animals but had no effect on that of parous cows (Table 4 ). An increase of approximately 0.11 units in milk protein content was estimated by increasing the prepartum dietary $\mathrm{CP}$ from 12 to $15 \%$ of $\mathrm{DM}$ in nulliparous cows (Table 5). An interaction $(P=0.04)$ between quadratic effect of prepartum $\mathrm{CP}$ and parity $(\mathrm{CP} \times \mathrm{CP} \times$ parity $)$ was observed for milk protein yield (Table 4$)$. A quadratic increase $(P=0.02)$ in milk protein yield was observed in nulliparous cows, but no effect of dietary CP was detected in parous cows (Table 4). Milk protein yield increased up to $0.99 \mathrm{~kg} / \mathrm{d}$ in nul- liparous cows when $\mathrm{CP}$ was approximately $15 \%$ of the diet DM (Figure 3B and Table 5).

Postpartum BW, BW change daily, and BCS were reported in 20, 18, and 21 experiments, respectively (Table 3). The mean BW and change in BW postpartum were not influenced by prepartum dietary CP (Table 4). An interaction $(P<0.001)$ between the linear effect of dietary $\mathrm{CP}$ and parity was observed for postpartum BCS. An increment of 0.15 units in BCS was estimated by increasing the prepartum dietary CP from 12 to $15 \%$ of DM in nulliparous cows (Table 5); however, the same increase in prepartum CP did not influence BCS in parous cows. The beta coefficients and
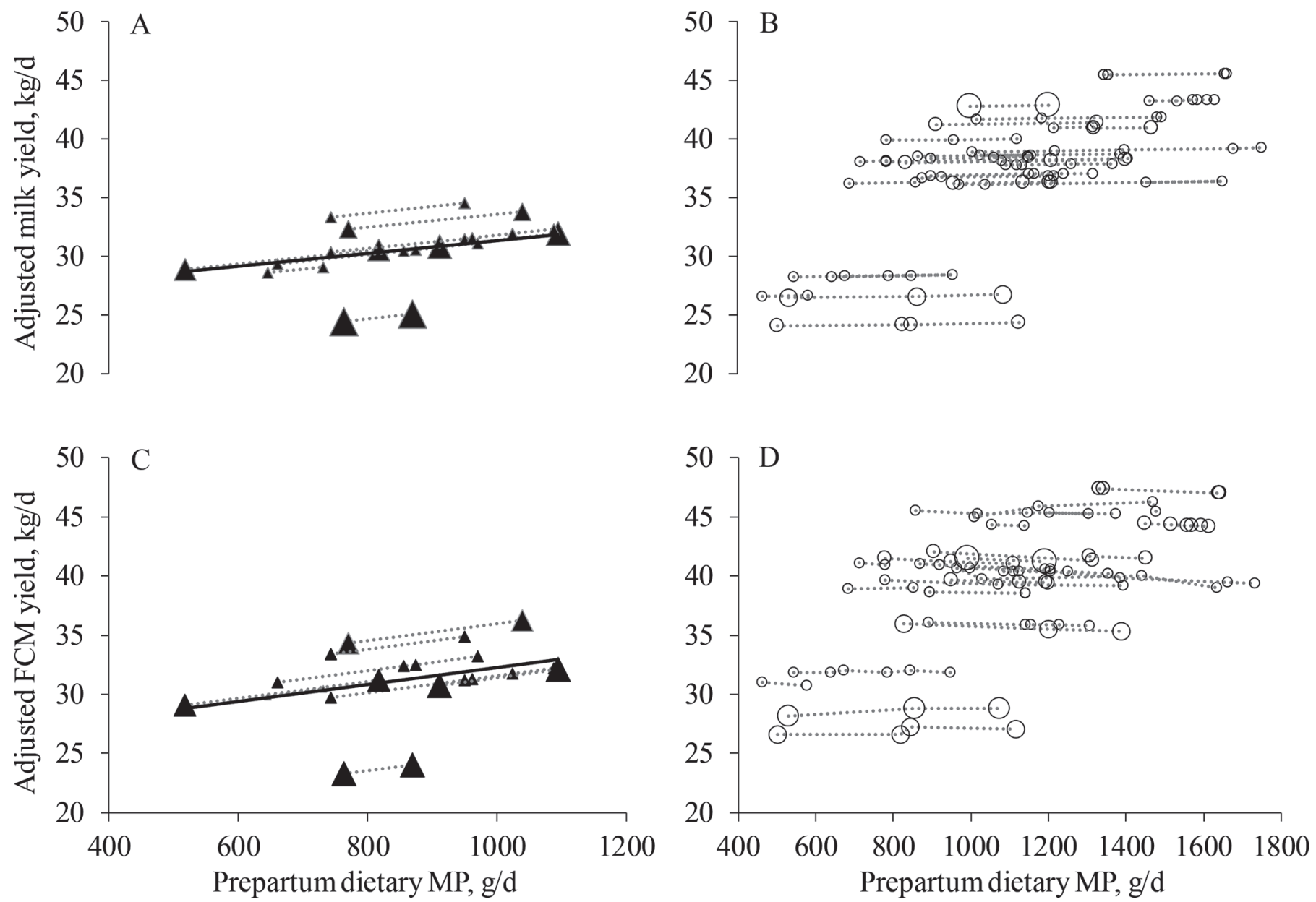

Figure 4. Postpartum performance in nulliparous $(\boldsymbol{\Delta})$ and parous $(\bigcirc)$ cows according to the predicted supply of MP prepartum. Dotted lines connect predicted values within experiment. Continuous line, presented only when statistical significance was observed, depicts the response to supply of MP prepartum. Milk yield nulliparous cows $($ A): linear effect of prepartum dietary MP $(P=0.02)$, quadratic effect of prepartum dietary MP $(P=0.26)$. Milk yield parous cows $(B)$ : linear effect of prepartum dietary MP $(P=0.54)$, quadratic effect of prepartum dietary MP $(P=0.79)$. Fat-corrected milk yield nulliparous cows $(\mathrm{C})$ : linear effect of prepartum dietary MP $(P=0.01)$, quadratic effect of prepartum dietary MP $(P=0.20)$. Fat-corrected milk yield parous cows $(\mathrm{D})$ : linear effect of prepartum dietary MP $(P=0.14)$, quadratic effect of prepartum dietary MP $(P=0.82)$. Nulliparous cows: lactation 0 prepartum and lactation 1 postpartum; Parous cows: lactation $>0$ prepartum. (A) 8 experiments and 27 treatment means; $(\mathrm{B})=25$ experiments and 98 treatment means; (C) 8 experiments and 27 treatment means; (D) 25 experiments and 98 treatment means. The size of the symbols represents the weight of treatment mean in the analysis. 
respective standard errors for predictors retained in the final models for the effects of prepartum dietary $\mathrm{CP}$ on postpartum performance in dairy cows are presented in Supplemental Table S1 (https://doi.org/10.3168/jds .2018-16043).

\section{Effect of Prepartum Supply of MP on Prepartum Performance}

Postpartum DMI was reported in 20 experiments with 87 treatment means; however, only 3 of those experiments with 8 treatment means reported data separately for nulliparous cows (Table 3). As expected, prepartum DMI was positively associated $(P<0.001)$ with the predicted supply of MP calculated using NRC (2001); therefore, prepartum DMI was not statistically analyzed in response to supply of MP because of the conditional relationship between the 2 variables. Predicted prepartum supply of MP differed substantially between parity groups (Table 2); thus, responses to MP were analyzed separately for nulliparous and parous cows to accommodate the distinct ranges of protein supplies.

Prepartum supply of MP had a positive linear $(P=$ 0.006 , Table 6) effect on prepartum BW in nulliparous and an increment of $13 \mathrm{~kg}$ of BW was observed when MP supply increased from 800 to $1,000 \mathrm{~g} / \mathrm{d}$ (Table 7). Similarly, BW responded linearly $(P=0.04$, Table 6$)$
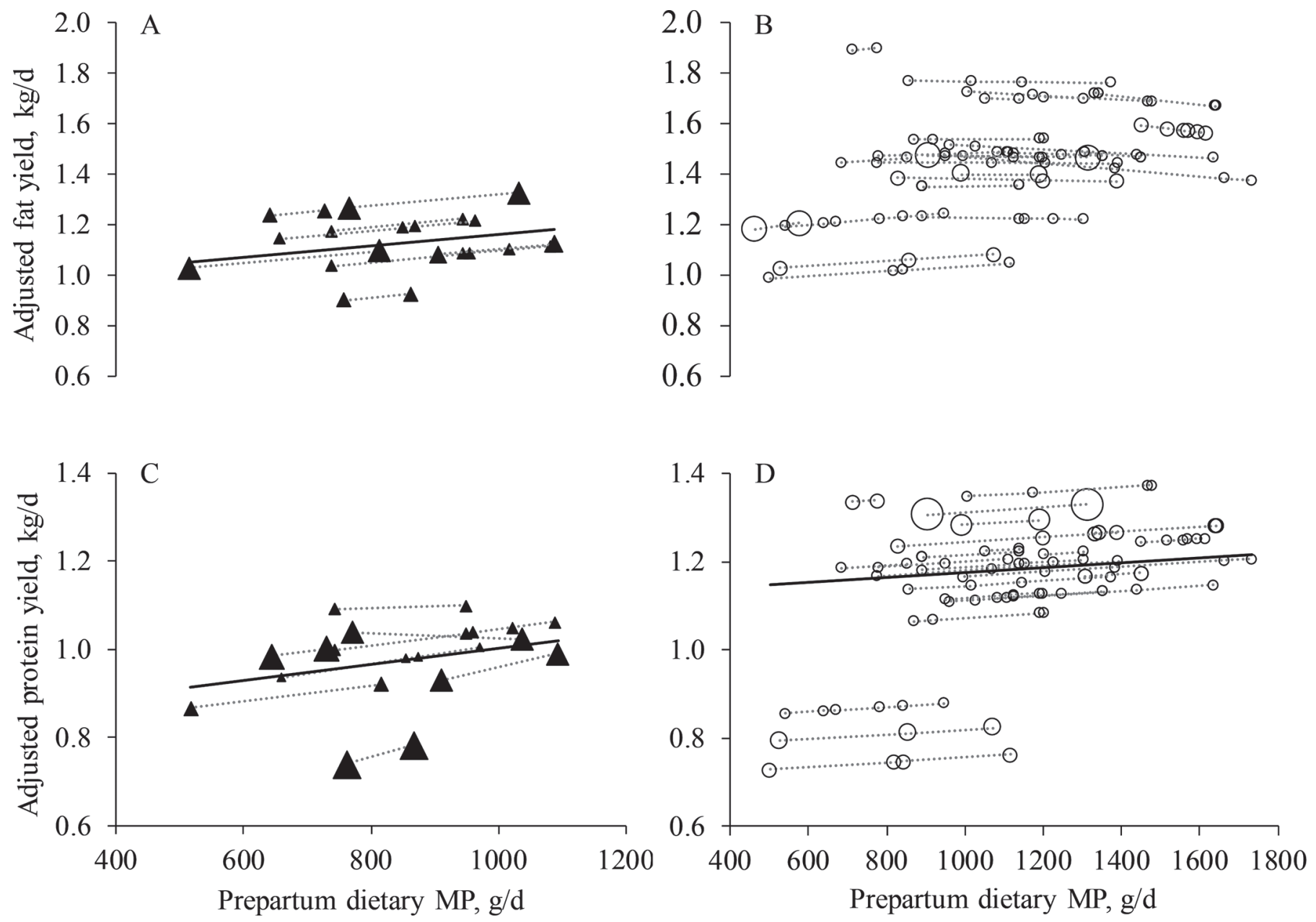

Figure 5. Postpartum performance in nulliparous $(\mathbf{\Lambda})$ and parous $(\bigcirc)$ cows according to the predicted supply of MP prepartum. Dotted lines connect predicted values within experiment. Continuous line, presented only when statistical significance was observed, depicts the response to supply of MP prepartum. Fat yield nulliparous cows (A): linear effect of prepartum dietary MP $(P=0.02)$, quadratic effect of prepartum dietary MP $(P=0.24)$. Fat yield parous cows $(\mathrm{B})$ : linear effect of prepartum dietary MP $(P=0.37)$, quadratic effect of prepartum dietary MP $(P=$ 0.65). Protein yield nulliparous cows $(\mathrm{C})$ : linear effect of prepartum dietary MP $(P=0.04)$, quadratic effect of prepartum dietary MP $(P=$ $0.18)$. Protein yield parous cows $(\mathrm{D})$ : linear effect of prepartum dietary MP $(P=0.003)$, quadratic effect of prepartum dietary MP $(P=0.29)$. Nulliparous cows: lactation 0 prepartum and lactation 1 postpartum; Parous cows: lactation $>0$ prepartum. (A) 8 experiments and 27 treatment means; $(B)=25$ experiments and 98 treatment means; (C) 8 experiments and 27 treatment means; (D) 24 experiments and 96 treatment means. The size of the symbols represent the weight of treatment mean in the analysis. 

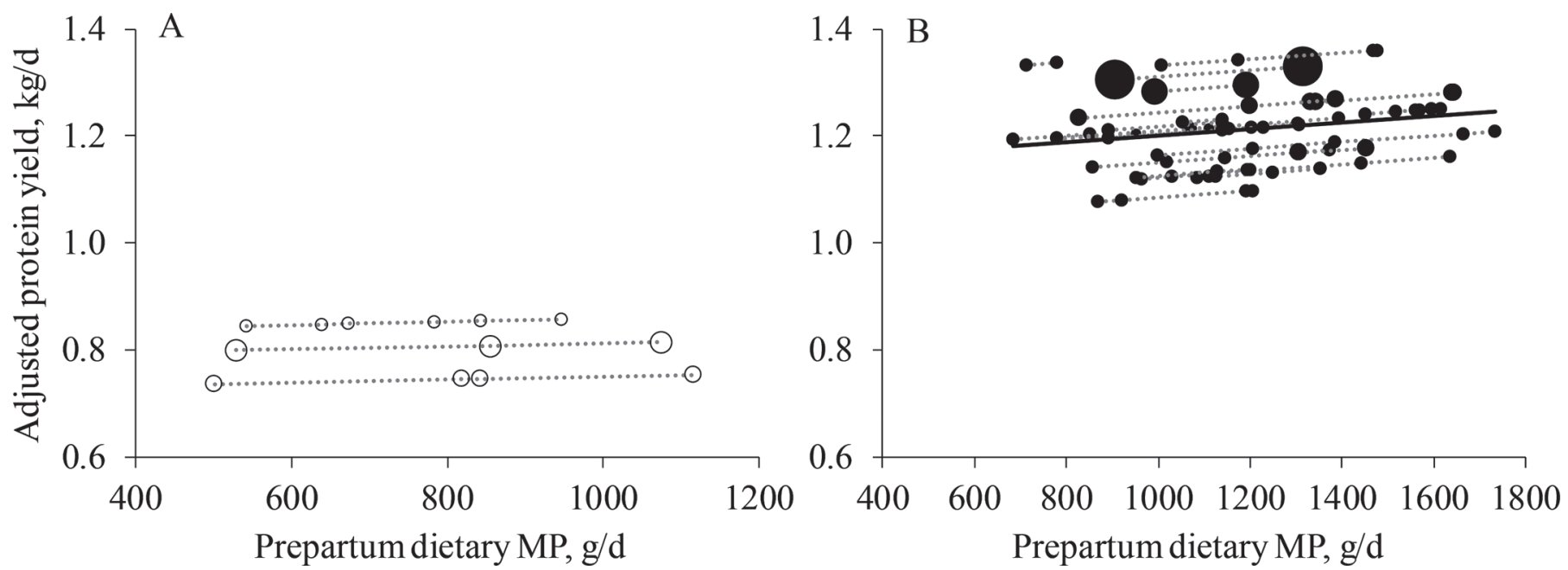

Figure 6. Protein yield response in low $(\bigcirc$; milk $<28 \mathrm{~kg} / \mathrm{d})$ and high $(\mathbf{\bullet}$; milk $>36 \mathrm{~kg} / \mathrm{d})$ producing parous cows according to the predicted supply of MP prepartum. Dotted lines connect predicted values within experiment. Continuous line, presented only when statistical significance was observed, depicts the response to supply of MP prepartum. Low producing parous cows (A): linear effect of prepartum dietary MP $(P=$ $0.33)$, quadratic effect of prepartum dietary MP $(P=0.78)$. High producing parous cows $(\mathrm{B})$ : linear effect of prepartum dietary MP $(P=0.004)$, quadratic effect of prepartum dietary MP $(P=0.59)$. Parous cows: lactation $>0$ prepartum. (A) 3 experiments with 13 treatment means; (B) 21 experiments and 83 treatment means. The size of the symbols represents the weight of treatment mean in the analysis.

to increasing prepartum MP supply in parous cows and an increment of $18 \mathrm{~kg}$ in prepartum BW was observed when MP increased from 900 to $1,200 \mathrm{~g} / \mathrm{d}$ (Table 7). Increasing the supply of MP prepartum increased $(P$ $=0.03)$ BCS prepartum in nulliparous but not in parous cows (Tables 6 and 7). The beta coefficients and respective standard errors for predictors retained in the final models for the effects of prepartum dietary MP on prepartum performance in dairy cows are presented in Supplemental Table S2 (https://doi.org/10.3168/jds .2018-16043).

\section{Effect of Prepartum Supply of MP on Postpartum Performance}

Increased MP prepartum linearly increased $(P<$ 0.001) postpartum DMI in nulliparous cows, but in parous cows, a tendency $(P=0.07)$ for a quadratic response was observed (Table 6). An increase of 1.7 $\mathrm{kg} / \mathrm{d}$ in DMI was estimated by increasing the prepartum supply of MP from 800 to $1,000 \mathrm{~g} / \mathrm{d}$ in nulliparous cows (Table 7 ). In parous cows, the quadratic response in DMI was maximized at $19.8 \mathrm{~kg} / \mathrm{d}$ when prepartum MP supply was $1,000 \mathrm{~g} / \mathrm{d}$ (Table 7). Increased prepartum MP supply linearly increased $(P=0.02)$ milk yield in nulliparous cows, with an estimated increment of $1.1 \mathrm{~kg} / \mathrm{d}$ when the supply increased from 800 to 1,000 $\mathrm{g} / \mathrm{d}$ (Figure 4A and Table 7). No effect of prepartum MP was observed for milk yield in parous cows. Fatcorrected milk yield was influenced linearly $(P=0.01)$ by altering the prepartum dietary supply of MP in nul- liparous cows (Table 6), and an increment of $1.4 \mathrm{~kg} / \mathrm{d}$ in FCM was estimated when MP prepartum increased from 800 to $1,000 \mathrm{~g} / \mathrm{d}$ (Figure $4 \mathrm{C}$ and Table 7). Conversely, prepartum supply of MP did not affect FCM yield in parous cows (Figure 4D and Tables 6 and 7 ).

Fat yield in nulliparous cows increased linearly $(P=$ 0.02 ) with an increased supply of MP prepartum (Table 6 ), and an increment of $0.05 \mathrm{~kg} / \mathrm{d}$ was estimated when MP increased from 800 to $1,000 \mathrm{~g} / \mathrm{d}$ (Figure $5 \mathrm{~A}$ and Table 7). Nevertheless, prepartum supply of MP did not affect fat yield in parous cows (Figure 5B and Table $6)$. Increasing MP caused a linear increase $(P=0.02)$ in concentration of protein in milk in nulliparous but not in parous cows (Table 6). Milk protein yield increased in a linear fashion in nulliparous $(P=0.04)$ and parous $(P=0.003)$ cows with increased supply of MP (Figures $5 \mathrm{C}$ and $5 \mathrm{D}$ and Table 6$)$. Nevertheless, the increase $(P$ $=0.004)$ in milk protein yield in parous cows with additional MP was only observed in experiments in which milk yield was $>36 \mathrm{~kg} / \mathrm{d}$ (coefficient $\pm \mathrm{SE}, 0.0000600$ $\pm 0.0000200)$. No effect $(P=0.33)$ of prepartum MP supply was observed for milk protein yield in parous cows in experiments in which production was $<28 \mathrm{~kg} / \mathrm{d}$ (coefficient \pm SE, $0.0000280 \pm 0.0000270$; Figure 6). Prepartum MP tended $(P=0.06)$ to have a positive linear effect on postpartum BW in nulliparous cows but no effects were observed in parous cows (Tables 6 and 7). Daily change in BW did not differ between nulliparous and parous cows (Table 6). Prepartum MP had a linear positive effect on postpartum BCS in both nulliparous and parous cows (Table 7 ). The beta coef- 
ficients and respective standard errors for predictors retained in the final models for the effects of prepartum dietary MP on postpartum performance in dairy cows are presented in Supplemental Table S2 (https://doi .org/10.3168/jds.2018-16043).

\section{DISCUSSION}

Important goals of prepartum diet formulation are to meet the nutrient needs of the dam and those of the growing fetus at the same time that postpartum health and performance are improved. Many prepartum dietary manipulations have long-lasting effects postpartum (Lean et al., 2014), although individual experiments are often unable to detect those effects in part because of limited sample size for the observed variability among cows in early lactation. In the present study, we used a meta-analytical approach to quantify the effect of prepartum dietary $\mathrm{CP}$ content or predicted supply of MP on production performance of nulliparous and parous cows. Results showed that increasing prepartum dietary $\mathrm{CP}$ content increased pre- and postpartum DMI and yields of fat and protein in nulliparous cows, but only minor or no effects were observed in parous cows. Perhaps more important than $\mathrm{CP}$, when the supply of MP prepartum increased from approximately $500 \mathrm{~g} / \mathrm{d}$ to up to almost $1,100 \mathrm{~g} / \mathrm{d}$, postpartum intake and yields of milk, FCM, milk fat and protein all increased in nulliparous cows. Conversely, an increase in MP supply in parous cows to $1,700 \mathrm{~g} / \mathrm{d}$ did not affect DMI or yields of milk, FCM, or milk fat, but only improved milk protein yield in experiments with high-producing cows.

Previous narrative reviews of the literature have suggested that responses to increasing dietary protein prepartum were dependent on the ingredient composition or nutrient content of the diet fed (Bell et al., 2000; Stockdale and Roche, 2002). The authors suggested that responses to manipulating the content or degradability of protein fed prepartum with the aim of increasing the supply of MP had been variable, with some experiments showing benefits to yields of milk and milk protein and many showing no effect on postpartum performance (Bell et al., 2000; Stockdale and Roche, 2002). It was suggested that part of the inconsistency in responses reflected the variability in factors other than dietary $\mathrm{CP}$, such as days on dietary treatments, the $\mathrm{NE}_{\mathrm{L}}$ content of the diet, and parity of cows. Kokkonen (2014) investigated sources of variation in the effect of prepartum protein supplementation on early lactation performance in dairy cows. The author observed that responses to dietary protein on DMI and yields of milk and milk protein differed according to forage source. For experiments in which cows were fed straw- or hay-based diets, increasing the content of CP or RUP improved postpartum intake and yields of milk and milk protein. Alternatively, the same $\mathrm{CP}$ or RUP either tended to or significantly reduced intake and yields of milk or milk protein when cows were fed corn silage-based diets (Kokkonen, 2014). Digestibility of corn silage is greater than that of straw or straw/hay combination, which likely would increase the supply of microbial protein to the cow, thereby reducing the needs for supplemental protein to meet the AA needs prepartum. This might explain the benefits of increasing dietary CP or RUP when prepartum diets contained low quality forages, but does not necessarily explain the negative effects when cows were fed corn silage. Others have suggested that improvements in postpartum performance with additional protein prepartum were observed only when the control diet contained up to $12 \%$ CP (Bell et al., 2000).

The approach taken in the current study was to use mixed model meta-analysis to evaluate the effects of manipulating prepartum protein on performance when controlling for potential confounders such as diet $\mathrm{NE}_{\mathrm{L}}$ and parity group. Diet $\mathrm{NE}_{\mathrm{L}}$ should account for some, but not necessarily all, variability in forage type and quality. Nevertheless, the selected methodology was used in an attempt to empirically define the dietary CP concentration or MP supply required by dairy cows to optimize yields of milk and milk components. It is clear from the present study that the benefits of manipulating dietary protein prepartum vary with parity group, and nulliparous cows require diets with additional protein or with increased supply of MP, at least up to $1,100 \mathrm{~g} / \mathrm{d}$. Nulliparous cows are known to have reduced DMI compared with parous cows prepartum (Hayirli et al., 2002), which influences not only protein intake but also microbial protein yield, thereby affecting MP supply. In fact, experiments reporting data for nulliparous cows clearly showed that the supply of MP prepartum was limited to $1,100 \mathrm{~g} / \mathrm{d}$, substantially less than the 1,700 g upper limit observed for experiments with parous cows. At the same CP content, when protein varied from 12 to $15 \%$ of the diet DM, diets fed to parous cows supplied 140 to $290 \mathrm{~g}$ more MP than those fed to nulliparous cows (Supplemental Figure S1; https:/ /doi.org/10.3168/jds.2018-16043). Because nulliparous cows have increased AA needs for growth and microbial protein usually has an AA profile that resembles that of lean tissue (NRC, 2001), it is not surprising that results showed benefits of increasing dietary CP content to performance of nulliparous cows, but little or no effect was observed in parous cows.

The improvements in lactation performance observed in nulliparous cows fed increased amounts of $\mathrm{CP}$ or MP are likely explained by the increased DMI pre- and 
postpartum. In general, dietary $\mathrm{CP}$ has little effect on DMI prepartum in dairy cows, but most of the data evaluated focused on parous cows (Hayirli et al., 2002). In the present study, feeding diets with more CP did not benefit DMI in prepartum parous cows. Alternatively, increasing prepartum dietary $\mathrm{CP}$ content tended to increase prepartum and increased postpartum DMI in nulliparous cows. The extra $2.2 \mathrm{~kg}$ of postpartum DMI estimated when diets fed to nulliparous cows prepartum contained 15\% compared with $12 \%$ CP likely explain the increments in yields of milk components and the improved BCS postpartum. The increased postpartum DMI observed in nulliparous cows when both CP and MP increased prepartum would supply more energy and AA to support lactation performance, thereby justifying the increased yields of milk, FCM, and milk components. Although we suggest that the additional intake might explain differences in productive performance in nulliparous fed additional protein prepartum, it is important to note that only a portion of the experiments reported DMI postpartum.

Nulliparous cows at calving typically weigh around 85 to $90 \%$ of the mature $\mathrm{BW}$ for the breed, and a positive association exists between weight at calving and first-lactation milk yield (Heinrichs and Losinger, 1998). In the experiments used in the present data set, nulliparous cows had a mean and median BW prepartum that represented 86.7 and $88.2 \%$ of the mean and median BW of parous cows, respectively. Therefore, it is expected that nulliparous cows had additional AA needs for growth, which might have resulted in extra requirements for lean tissue accretion during late gestation. At the same dietary CP content, nulliparous cows would have a smaller quantity of MP supplied by the diet because intake of DM is usually less in nulliparous than parous cows (Hayirli et al., 2002). Using the results from the database, at $12 \% \mathrm{CP}$, the supply of MP to nulliparous was only $790 \mathrm{~g} / \mathrm{d}$, which is not sufficient to meet the needs for maintenance, pregnant uterus tissue accretion, and growth (NRC, 2001). In the last month of gestation, the weight of the mammary gland increases from 1.99 to $2.65 \%$ of the BW of nulliparous cows, at the same time that mammary parenchyma weight increases from 1.34 to $1.78 \%$ of BW (Swanson and Poffenbarger, 1979). Growth rate of the mammary gland in nulliparous cows averages $33 \%$ per month based on parenchymal N deposition (Swanson and Poffenbarger, 1979). At the same time, the change in body growth in the Holstein nulliparous cows gaining $1 \mathrm{~kg}$ of $\mathrm{BW} / \mathrm{d}$ would be approximately 5 to $6 \%$ per month. Others also have documented important accretion of mammary tissue in the last weeks of gestation in dairy cows (Capuco et al., 1997) and ewes (McNeill et al., 1997).
Estimates from Bell et al. (2000) using data from mammary tissue growth in dairy cows (Capuco et al., 1997) and protein accretion in prepartum ewes (McNeill et al., 1997) suggested that an additional $120 \mathrm{~g} / \mathrm{d}$ of MP might be needed to meet the AA needs for mammary tissue accretion in prepartum dairy cows (Bell et al., 1995). A similar value of $130 \mathrm{~g} / \mathrm{d}$ of MP is cited by the NRC (2001), although it is not included in the current recommendations. Limiting the supply of MP to nulliparous cows, either because of less intake than parous cows (Hayirli et al., 2002) or because additional needs for growth, might limit mammary development and subsequent milk yield. Little is known about protein reserves and mobilization of AA to meet the needs when cows are in negative $\mathrm{N}$ balance in early lactation, particularly in nulliparous cows. Some have suggested that feeding additional protein to late-gestation primigravid cows might increase maternal reserves at calving and provide potential for mobilization of tissue protein to contribute to yields of milk (Adachi et al., 2006) and milk protein in the subsequent early lactation (van Saun et al., 1993).

McNeill et al. (1997) fed late-pregnant ewes diets containing low $(7.9 \% \mathrm{CP})$, moderate $(11.6 \% \mathrm{CP})$, or high $(15.7 \% \mathrm{CP})$ protein from 111 to $140 \mathrm{~d}$ of gestation and evaluated tissue $\mathrm{N}$ accretion. Ewes in all 3 treatments had $\mathrm{N}$ accretion into the gravid uterus and mammary gland, but accretions in both tissues were greater when ewes were fed the diets with moderate or high protein contents. More importantly, ewes fed the low and moderate dietary protein accreted $\mathrm{N}$ into the gravid uterus and mammary gland at the expense of carcass $\mathrm{N}$, which decreased in those diets. In contrast, ewes fed the prepartum diet containing $15.7 \% \mathrm{CP}$, which was supplemented with fish meal, not only had greater $\mathrm{N}$ balance than those fed the low or moderate protein diets, but they had gravid uterus and mammary $\mathrm{N}$ accretion concurrent with carcass $\mathrm{N}$ accretion. These data suggest that, in late-pregnant ewes, diets with limited supply of protein might limit mammary tissue accretion, and partition of $\mathrm{N}$ in ewes fed those diets results in skeletal muscle protein mobilization. In dairy cows, indirect measurements of body protein mobilization by measurement of plasma 3-methylhistidine and ultrasonography of muscle thickness suggested that loss of body protein starts before calving until 2 wk in lactation (van der Drift et al., 2012). In fact, measurements of body composition in transition cows using deuterium oxide dilution technique showed a loss of $21 \mathrm{~kg}$ of body protein in parous cows between 2 wk prepartum and 5 wk of lactation (Komaragiri and Erdman, 1997). It is known that diet can influence the AA composition of skeletal muscle in cattle (Holló et al., 2007), which might be mobilized during periods of inadequate supply 
of metabolizable AA (Komaragiri and Erdman, 1997; McNeill et al., 1997). Therefore, providing additional MP prepartum might support mammary growth and increase the pool of AA available for mobilization with the onset of lactation, particularly in nulliparous cows. Nevertheless, to our knowledge, no data are available in dairy cattle demonstrating the effects of altering prepartum protein intake on body protein accretion in nulliparous cows.

It has been suggested that diets with $12 \% \mathrm{CP}$ fed prepartum would be sufficient to meet the needs of MP of parous cows (NRC, 2001). This value, in part, reflects the needs to provide sufficient $\mathrm{N}, \mathrm{AA}$, and peptides to maintain proper rumen microbial metabolism and digestion. Dorshorst and Grummer (2002) increased the $\mathrm{CP}$ content of diets fed prepartum to nulliparous and parous cows from 9.1 or $11.2 \%$ by adding urea and evaluated DMI and aspects of rumen digestion. Intake of DM and concentrations of acetate or propionate did not differ with dietary $\mathrm{CP}$ fed, although in sacco rumen degradation of NDF improved with additional $\mathrm{CP}$, likely because cows fed $9.1 \% \mathrm{CP}$ had low rumen $\mathrm{NH}_{3}$ concentrations that might have limited fibrolytic microbial growth. At $12 \% \mathrm{CP}$, the current database predicted a supply of approximately $920 \mathrm{~g} / \mathrm{d}$ of MP, which would be sufficient to meet the needs for maintenance and pregnant uterus tissue accretion (Bell et al., 1995; NRC, 2001). At $920 \mathrm{~g}$ of $\mathrm{MP} / \mathrm{d}$ for parous cows, the current results showed no benefit of feeding additional protein, except for milk protein yield in experiments with high-producing cows. We speculate that the improvements in milk protein yield observed with incremental supply of MP in high-producing parous cows suggest either improved mammary tissue accretion or an increased pool of labile protein that can be mobilized in early lactation when production is high.

The intake of DM prepartum was expected to influence the supply of MP and it has been shown that increased prepartum DMI might influence postpartum performance (Bertics et al., 1992). Because of that, additional statistical models were created to analyze the data with MP as percentage of DM to understand whether manipulating the supply of MP per kilogram of DM consumed would influence lactation performance (results not shown). In support of the findings with intake of MP as grams per day, the same responses were observed when MP was expressed as a percentage of DMI. Yields of milk, FCM, fat, and protein increased in nulliparous cows with increased MP per kilogram of DMI. However, in parous cows, only yield of milk protein increased with increased concentration of MP per kilogram of DMI. These results support the findings of the effects of supply of MP as grams per day on performance of nulliparous and parous cows.
A limitation of the present study is that we were not able to evaluate the effects of prepartum protein on health of dairy cows. Most experiments did not report incidence of diseases. One of the objectives of prepartum diets is to minimize the risk of health disorders, particularly those of a metabolic nature. Although epidemiological studies have suggested that increased prepartum protein is associated with improved peripartum health (Curtis et al., 1985), no evidence from the current literature has established recommendations for protein feeding prepartum to improve postpartum health. Manipulating prepartum dietary protein might have influenced postpartum health, which could explain improved production in response to additional $\mathrm{CP}$ or MP. Nevertheless, that assumption would be valid for nulliparous animals because the effect of prepartum protein on parous cows was marginal. This area warrants further investigation.

The NRC (2001) estimates that a nulliparous Holstein cow weighing $600 \mathrm{~kg}$, at $270 \mathrm{~d}$ of gestation, and consuming $10 \mathrm{~kg}$ of DM/d requires approximately 1,050 $\mathrm{g} / \mathrm{d}$ of MP to meet needs for maintenance $(450 \mathrm{~g} / \mathrm{d})$, pregnancy $(330 \mathrm{~g} / \mathrm{d})$, and growth $(270 \mathrm{~g} / \mathrm{d})$. In contrast, a parous Holstein cow weighing $690 \mathrm{~kg}$ at 270 $\mathrm{d}$ of gestation and consuming $12 \mathrm{~kg}$ of $\mathrm{DM} / \mathrm{d}$ requires approximately $820 \mathrm{~g} / \mathrm{d}$ of MP to meet the needs for maintenance $(480 \mathrm{~g} / \mathrm{d}$ and pregnancy $(340 \mathrm{~g} / \mathrm{d})$, with no additional needs for growth. Based on the mean supply of MP in Table 2, it is clear that a smaller proportion of experiments with nulliparous cows fed diets that met the estimated needs for absorbable AA compared with those using parous cows. The linear responses to supply of MP observed for postpartum DMI and yields of milk, FCM, and protein in nulliparous cows suggest that prepartum needs for absorbable AA are at least $1,100 \mathrm{~g} / \mathrm{d}$, which is close to the value suggested by the NRC (2001). Nevertheless, because the upper limit of MP was 1,094 g/d in the database analyzed, the needs might be greater than the suggested amount, although this speculation needs to be verified in future experiments. A possible reason for increased needs beyond $1,100 \mathrm{~g} / \mathrm{d}$ in nulliparous cows might be the additional tissue accretion by the mammary gland (Bell et al., 2000), which is not accounted for by the NRC (2001).

\section{CONCLUSIONS}

Increasing prepartum dietary protein content increased pre- and postpartum intakes, BW, and BCS in nulliparous cows but not parous cows. Nulliparous cows produced more milk, FCM, milk fat, and protein as the supply of MP increased. Based on the diets fed and respective DMI, the upper limit of MP supplied was $1,100 \mathrm{~g} / \mathrm{d}$ in nulliparous cows, which was achieved 
when diets contained 14 to $15 \%$ CP. However, increasing the supply of MP in parous cows had minor effects on postpartum performance. Yields of milk, FCM, and milk fat were not influenced by prepartum MP in parous cows; however, in experiments with cows producing $>36 \mathrm{~kg}$ of milk/d, milk protein yield increased as supply of MP prepartum increased. These findings support the concept of feeding prepartum diets with MP to meet current National Research Council recommendations (NRC, 2001), which are greater for nulliparous than for parous cows. Collectively, feeding prepartum nulliparous cows diets with approximately 14 to $15 \%$ CP to supply $1,100 \mathrm{~g} / \mathrm{d}$ of MP benefits performance, whereas for high-producing parous cows, only milk protein improved when prepartum diets supplied more than $800 \mathrm{~g} / \mathrm{d}$ of MP.

\section{ACKNOWLEDGMENTS}

The authors thank the researchers who provided detailed data not available in the published manuscripts. The assistance of Murilo R. Carvalho and Achilles Vieira-Neto (University of Florida) with data extraction and revision is greatly appreciated.

\section{REFERENCES}

Adachi, N., T. Kusuhara, I. Nonaka, and F. Terada. 2006. Effect of close-up dry period protein level on preparturiental nitrogen balance and lactating performance of primigravid and multiparous Holstein cows. Asian-Aust. J. Anim. Sci. 19:831-836.

Bell, A. W., W. S. Burhans, and T. R. Overton. 2000. Protein nutrition in late pregnancy, maternal protein reserves and lactation performance in dairy cows. Proc. Nutr. Soc. 59:119-126.

Bell, A. W., R. Slepetis, and R. A. Ehrhardt. 1995. Growth and accretion of energy and protein in the gravid uterus during late pregnancy in Holstein cows. J. Dairy Sci. 78:1954-1961.

Bertics, S. J., R. R. Grummer, C. Cardoniga-Valino, and E. E. Stoddard. 1992. Effect of prepartum dry matter intake on liver triglyceride concentration and early lactation. J. Dairy Sci. 75:1914-1922.

Capuco, A. V., R. M. Akers, and J. J. Smith. 1997. Mammary growth in Holstein cows during the dry period: Quantification of nucleic acids and histology. J. Dairy Sci. 80:477-487.

Chew, B. P., F. R. Murdock, R. E. Riley, and J. K. Hillers. 1984. Influence of prepartum dietary crude protein on growth hormone, insulin, reproduction, and lactation of dairy cows. J. Dairy Sci. $67: 270-275$.

Crawley, D. D., and L. H. Kilmer. 1995. Effects of level and source of rumen degradable protein fed prepartum on postpartum performance of dairy cows. J. Dairy Sci. 78(Suppl. 1):266. (Abstr.)

Curtis, C. R., H. N. Erb, C. J. Sniffen, R. D. Smith, and D. S. Kronfeld. 1985. Path analysis of dry period nutrition, postpartum metabolic and reproductive disorders, and mastitis in Holstein cows. J. Dairy Sci. 68:2347-2360.

Dewhurst, R. J., J. M. Moorby, and M. S. Dhanoa. 2000. Effects of altering energy and protein supply to dairy cows during the dry period. 1. Intake, body condition, and milk production. J. Dairy Sci. 83:1782-1794.

Doepel, L., H. Lapierre, and J. J. Kennelly. 2002. Peripartum performance and metabolism of dairy cows in response to prepartum energy and protein intake. J. Dairy Sci. 85:2315-2334.
Dorshorst, M. E., and R. R. Grummer. 2002. Effect of day relative to parturition and dietary crude protein on rumen fermentation in prepartum transition cows. J. Dairy Sci. 85:2290-2298.

Drackley, J. K. 1999. Biology of dairy cows during the transition period: The final frontier? J. Dairy Sci. 82:2259-2273.

Drackley, J. K., and F. C. Cardoso. 2014. Prepartum and postpartum nutritional management to optimize fertility in high-yielding dairy cows in confined TMR systems. Animal 8(Suppl. 1):5-14.

Farahani, T. A., H. Amanlou, and M. Kazemi-Bonchenari. 2017. Effects of shortening the close-up period length coupled with increased supply of metabolizable protein on performance and metabolic status of multiparous Holstein cows. J. Dairy Sci. 100:61996217.

Greenfield, R. B., M. J. Cecava, T. R. Johnson, and S. S. Donkin. 2000. Impact of dietary protein amount and rumen undegradability on intake, peripartum liver triglyceride, plasma metabolites, and milk production in transition dairy cattle. J. Dairy Sci. 83:703-710.

Hartwell, J. R., M. J. Cecava, and S. S. Donkin. 2000. Impact of dietary rumen undegradable protein and rumen-protected choline on intake, peripartum liver triacylglyceride, plasma metabolites and milk production in transition dairy cows. J. Dairy Sci. 83:29072917.

Hayirli, A., R. R. Grummer, E. V. Nordheim, and P. M. Crump. 2002. Animal and dietary factors affecting feed intake during the prefresh transition period in Holsteins. J. Dairy Sci. 85:3430-3443.

Heinrichs, A. J., and W. C. Losinger. 1998. Growth of Holstein dairy heifers in the United States. J. Anim. Sci. 76:1254-1260.

Holló, G., K. Nuernberg, I. Holló, J. Csapó, J. Seregi, I. Repa, and K. Ender. 2007. Effect of feeding on the composition of longissimus muscle of Hungarian Grey and Holstein Friesian bulls. III Amino acid composition and mineral content. Arch. Tierzucht. $50: 575-586$

Hook, T. E. 1987. Protein effects on fetal growth, colostrum and calf immunoglobulins and lactation in dairy heifers. MSc Thesis. Colorado State Univ., Fort Collins.

Huyler, M. T., R. L. Kincaid, and D. F. Dostal. 1999. Metabolic and yield responses of multiparous Holstein cows to prepartum rumenundegradable protein. J. Dairy Sci. 82:527-536.

Kokkonen, T. 2014. Investigation of sources of variation in the effect of prepartum protein supplementation on early lactation performance of dairy cows. Livest. Sci. 163:41-50.

Komaragiri, M. V. S., and R. A. Erdman. 1997. Factors affecting body tissue mobilization in early lactation dairy cows. 1. Effect of dietary protein on mobilization of body fat and protein. J. Dairy Sci. 80:929-937.

Lean, I. J., P. J. DeGaris, P. Celi, D. M. McNeill, R. M. Rodney, and D. R. Fraser. 2014. Influencing the future: Interactions of skeleton, energy, protein and calcium during late gestation and early lactation. Anim. Prod. Sci. 54:1177-1189.

McNeill, D. M., R. Slepetis, R. A. Ehrhardt, D. M. Smith, and A. W Bell. 1997. Protein requirements of sheep in late pregnancy: Partitioning of nitrogen between gravid uterus and maternal tissues. J. Anim. Sci. 75:809-816.

Moher, D., A. Liberati, J. Tetzlaff, and D. G. Altman. 2009. The PRISMA Group. Preferred reporting items for systematic reviews and meta-analyses: The PRISMA statement. PLoS Med. 6:e1000097.

Moorby, J. M., R. J. Dewhurst, R. T. Evans, and W. J. Fisher. 2002 Effects of varying the energy and protein supply to dry cows on high-forage systems. Livest. Prod. Sci. 76:125-136.

NRC. 2001. Nutrient Requirements of Dairy Cattle. 7th rev. ed. Natl. Acad. Press, Washington, DC.

Park, A. F., J. E. Shirley, E. C. Titgemeyer, M. J. Meyer, M. J. VanBaale, and M. J. VandeHaar. 2002. Effect of protein level in prepartum diets on metabolism and performance of dairy cows. J. Dairy Sci. 85:1815-1828.

Piepho, H. P. 2009. Data transformation in statistical analysis of field trials with changing treatment variance. Agron. J. 101:865-869.

Phillips, G. J., T. L. Citron, J. S. Sage, K. A. Cummins, M. J. Cecava, and J. P. McNamara. 2003. Adaptations in body muscle and fat in 
transition dairy cattle fed differing amounts of protein and methionine hydroxy analog. J. Dairy Sci. 86:3634-3647.

Putnam, D. E., and G. A. Varga. 1998. Protein density and its influence on metabolite concentration and nitrogen retention by Holstein cows in late gestation. J. Dairy Sci. 81:1608-1618.

Putnam, D. E., G. A. Varga, and H. M. Dann. 1999. Metabolic and production responses to dietary protein and exogenous somatotropin in late gestation dairy cows. J. Dairy Sci. 82:982-995.

Robinson, P. H., J. M. Moorby, M. Arana, and T. Graham. 2004. Effect of feeding a high- or low-rumen escape protein supplement to dry Holstein cows and heifers within 3 weeks of calving on their productive and reproductive performance in the subsequent lactation. Anim. Feed Sci. Technol. 114:43-57.

Robinson, P. H., J. M. Moorby, M. Arana, R. Hinders, T. Graham, L. Castelanelli, and N. Barney. 2001. Influence of close-up dry period protein supplementation on productive and reproductive performance of Holstein cows in their subsequent lactation. J. Dairy Sci. 84:2273-2283.

Santos, J. E. P., E. J. DePeters, P. W. Jardon, and J. T. Huber. 2001. Effect of prepartum dietary protein level on performance of primigravid and multiparous Holstein dairy cows. J. Dairy Sci. 84:213-224.

Socha, M. T., D. E. Putnam, B. D. Garthwaite, N. L. Whitehouse, N. A. Kierstead, C. G. Schwab, G. A. Ducharme, and J. C. Robert. 2005. Improving intestinal amino ccid supply of pre and postpartum dairy cows with rumen-protected methionine and lysine. J. Dairy Sci. 88:1113-1126.

Stockdale, C. R., and J. R. Roche. 2002. A review of the energy and protein nutrition of dairy cows through their dry period and its impact on early lactation performance. Aust. J. Agric. Res. 53:737-753.

Swanson, E. W., and J. I. Poffenbarger. 1979. Mammary gland development of dairy heifers during their first gestation. J. Dairy Sci. 62:702-714.
Tesfa, A. T., T. Kokkonen, M. Tuori, T. Saukko, L.-A. Lindberg, R. Pösö, H. Saloniemi, and L. Syrjälä-Qvist. 2001. The effect of prepartum protein feeding on postpartum lactation performance of Ayrshire heifers and cows. Anim. Feed Sci. Technol. 10:73-89.

Tesfa, A. T., M. Tuori, L. Syrjälä-Qvist, R. Pösö, H. Saloniemi, K. Heinonen, K. Kivilahti, T. Saukko, and L.-A. Lindberg. 1999. The influence of dry period feeding on liver fat and postpartum performance of dairy cows. Anim. Feed Sci. Technol. 76:275-295.

van der Drift, S. G. A., M. Houweling, J. T. Schonewille, A. G. M. Tielens, and R. Jorritsma. 2012. Protein and fat mobilization and associations with serum $\beta$-hydroxybutyrate concentrations in dairy cows. J. Dairy Sci. 95:4911-4920.

van Saun. R. J., S. C. Idleman, and C. J. Sniffen. 1993. Effect of undegradable protein amount fed prepartum on postpartum production in first lactation Holstein cows. J. Dairy Sci. 76:236-244.

VandeHaar, M. J., G. Yousif, B. K. Sharma, T. H. Herdt, R. S. Emery, M. S. Allen, and J. S. Liesman. 1999. Effect of energy and protein density of prepartum diets on fat and protein metabolism of dairy cattle in the periparturient period. J. Dairy Sci. 82:1282-1295.

Wang, M., and B. J. Bushman. 1999. Integrating results through metaanalytic review using SAS software. SAS Institute Inc., Cary, NC.

Wasserstrom, V. M. 1996. Optimizing lysine and methionine nutrition during the periparturient and postparturient periods. PhD Diss. University of New Hampshire, Durham.

Wu, Z., R. J. Fisher, C. E. Polan, and C. G. Schwab. 1997. Lactational performance of cows fed low or high ruminally undegradable protein prepartum and supplemental methionine and lysine postpartum. J. Dairy Sci. 80:722-729.

Yazdi, M. H., H. Amanlou, and E. Mahjoubi. 2009. Increasing prepartum dietary crude protein using poultry by products meal dose does not influence performance of multiparous Holstein dairy cows. Pak. J. Biol. Sci. 12:1448-1454. 